\title{
Mixed siliciclastic-carbonate shelf sedimentation-Lower Devonian sequences of the SW Anti-Atlas, Morocco
}

\author{
Stefan Lubeseder ${ }^{\mathrm{a}, *}$, Jonathan Redfern ${ }^{\mathrm{a}}$, Lahcen Boutib ${ }^{\mathrm{b}}$ \\ a School of Earth, Atmospheric and Environmental Sciences, University of Manchester, Oxford Road, Manchester M13 9PL, UK \\ ${ }^{b}$ Office National des Hydrocarbures et des Mines (ONHYM), 34 Avenue Al Fadila, 10050 Rabat, Morocco
}

\section{A R T I C L E I N F O}

\section{Article history:}

Received 29 February 2008

Received in revised form 8 December 2008

Accepted 29 December 2008

\section{Keywords:}

Mixed carbonate-siliciclastic

Storm-dominated shelf

Cool-water

Sequence stratigraphy

Lower Devonian

Anti-Atlas

\begin{abstract}
A B S T R A C T
In the south-western Anti-Atlas of Morocco (Dra Plain), a continuous exposure of Lower Devonian sedimentary successions more than $400 \mathrm{~km}$ long provides an example of mixed siliciclastic-carbonate shelf sequences. The carbonates were deposited adjacent and down-dip to large lobes of storm-dominated deltaic complexes during sea-level lowstands, and subsequently transgressed over the $200 \mathrm{~m}$ thick prograding siliciclastic wedges during sea-level rise, depositing limestone units between 5 and $20 \mathrm{~m}$ thick. The deltaic lobes switched through time and caused alternating siliciclastic supply along the shoreline oblique-parallel transect. Condensed limestone successions formed in clastic sediment starved areas due to delta-complex abandonment.

Down-gradient, in outer ramp environments, the direct juxtaposition of carbonate and siliciclastic lithofacies associations comprising rhythmic lime mudstones/marls and massive shelf sandstones, provides the opportunity for mutual interpretation of their mode of deposition and bathymetry. This lateral relationship suggests that significant amalgamation took place in falling stage systems tracts to produce laterally extensive shelf sandstone-sheets on the outer ramp.

Two types of stacking patterns are observed in prograding siliciclastic wedges. A normal progradational shoreline pattern with well developed parasequence sets in the proximal ramp, and an abrupt-regressive succession in which the amalgamated shelf sandstones rest more or less directly on offshore siltstones in the distal ramp. In the latter case, the falling stage systems tract sandstones are overlain by a relatively thick cyclic alternation with brachiopod-rich storm-beds below a marked transgressive surface at the base of the capping transgressive limestones. The cyclic alternation is interpreted as lowstand systems tract deposits. Marked flooding surfaces on parasequence sets are Fe-enriched and contain abundant articulated brachiopods, indicating breaks in sedimentation and an overall deepening-upward facies from the underlying maximum regression and sequence boundary. These aggradational to retrogradational stacked lowstand systems tracts are thus rather 'transgressive', not regressive in character, as is commonly described in sequence stratigraphic ramp models.
\end{abstract}

(c) 2009 Elsevier B.V. All rights reserved.

\section{Introduction}

Mixed carbonate-siliciclastic systems may be subdivided into two end-member types. The first are productive shallow water carbonate ramps, which occasionally receive siliciclastic supply from the hinterland. Many of the published studies of ancient mixed systems belong to this group (e.g. Paradox Basin, Homewood and Eberli, 2000). The second type are siliciclastic shorelines, in which carbonate deposition is limited to the seaward side of the shelf. Where these systems have been described, in most cases emphasis has been on the

\footnotetext{
* Corresponding author. Current address: Wintershall Holding AG, Friedrich-EbertStrasse 160, 34119 Kassel, Germany. Fax: +49 5613011892

E-mail addresses: stefan_lubeseder@web.de (S. Lubeseder), jonathan.redfern@manchester.ac.uk (J. Redfern),BOUTIB@onhym.com (L. Boutib).
}

'clastic sedimentology', with the carbonate component being given less attention.

This study examines the facies and facies distribution of a siliciclastic-carbonate shelf, where sedimentary cycles are either carbonate- or siliciclastic-dominated, or where both components are present in equal proportion. The combined study of both the carbonate and siliciclastic facies provides additional constrains on the interpretation of their spatial-temporal distribution, bathymetry and depositional environment than one-component systems offer. The resulting model offers new ways of understanding apparent carbonate-only systems (carbonate ramps) of similar age and geological setting and stresses the need to incorporate the siliciclastic component even if this consists of the clay and silt fraction only (e.g. Lower Devonian carbonate ramp of the eastern Anti-Atlas). 


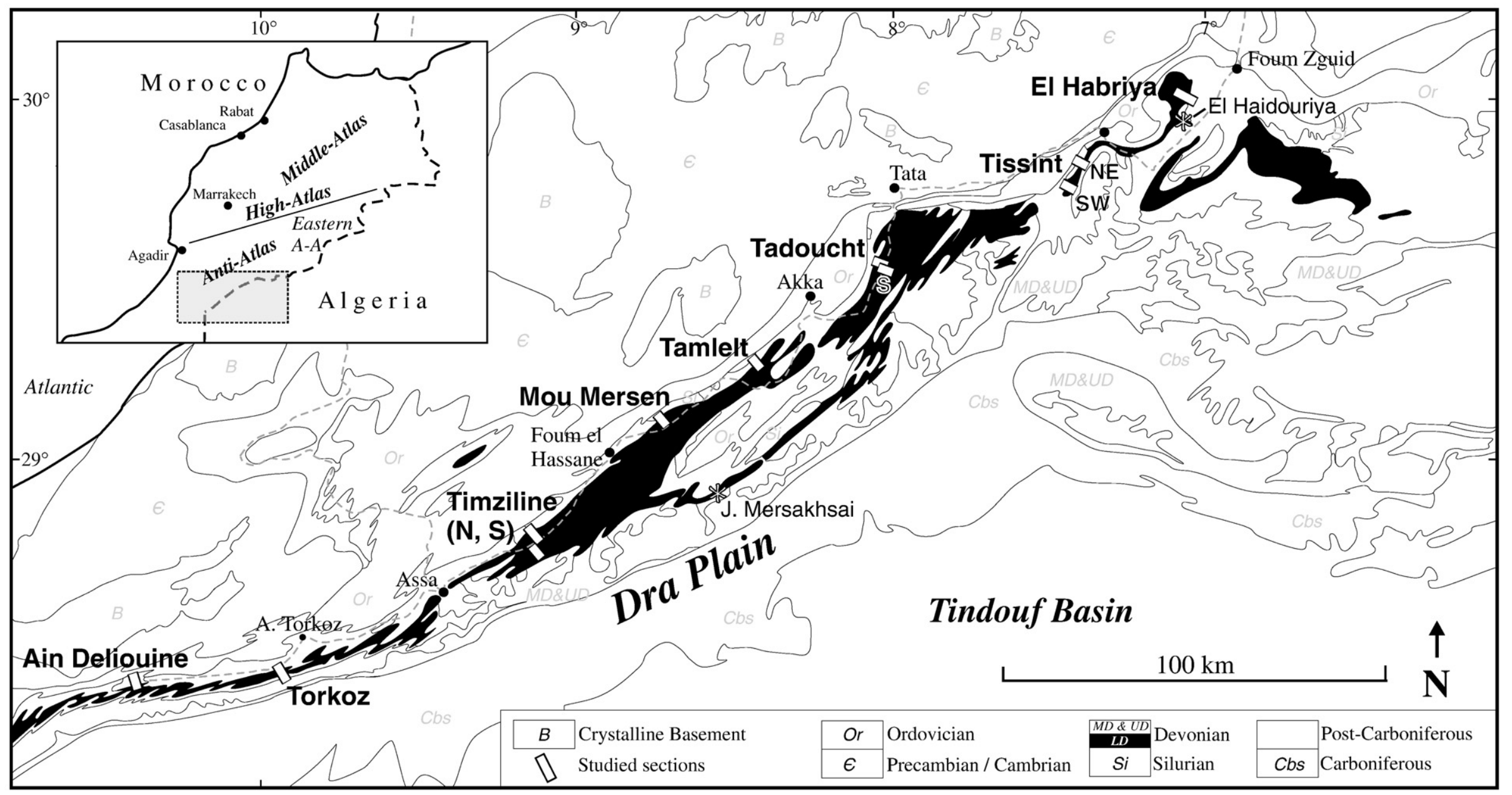

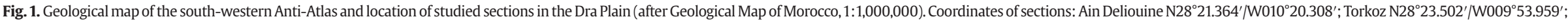

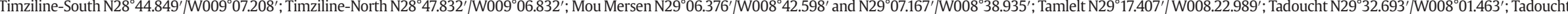

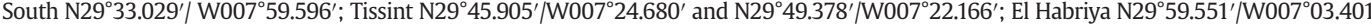


The models for ramp depositional sequences and their key bounding surfaces (e.g. Plint and Nummedal, 2000; Embry, 2002; Catuneanu, 2006) are extended in this paper to include the carbonate component. The objective is also to raise questions about the identification of the lowstand systems tract in ramp settings, and the position of this systems tract within the alternative transgressive/regressive (T/R) sequence model (Embry, 2002).

The south-western Anti-Atlas of Morocco has recently caught the attention of biostratigraphers (e.g. Jansen, 2001; El Hassani, 2004; Becker and Kirchgasser, 2007) as the area provides an excellent opportunity to overcome existing problems in correlating neritic to hemi-pelagic faunal biozones (e.g. brachiopod vs. conodont biozones). This significantly increased the biostratigraphic resolution and, combined with the stable marginal-cratonic setting of the Anti-Atlas during the Early Devonian, makes the stratigraphic record a favourable laboratory for a regional sequence framework that can be compared to global eustatic curves.

\section{Study area, geological background, and stratigraphic framework}

\subsection{Study area}

Lower Devonian rocks are almost continuously exposed over a distance of more than $400 \mathrm{~km}$ in the south-western Anti-Atlas Dra Plain (Fig. 1). The area is characterised by sets of anticlines and synclines which form part of the Hercynian foreland fold-belt (Caritg et al., 2004). Thirteen sections were measured along a regional transect, of which seven complete sections are presented in this study, with a log spacing of 32 to $88 \mathrm{~km}$.

\subsection{Geological background}

The Palaeozoic sediments of the Anti-Atlas were deposited on the northern margin of the Saharan craton. A general deepening trend towards the north-west is recognised on the craton, with modifications caused by low-relief palaeohighs separating intra-cratonic basins (Boote et al., 1998).

During the late Ordovician, peri-glacial, marine sandstones covered large parts of North Africa. A post-glacial early Silurian transgression shifted the shoreline far southwards, leading to widespread graptolite shale deposition. Soon after this transgression, deltaic sediments started to prograde during the early Silurian in Libya, marking the onset of a major regression that continued throughout the Silurian (Berry and Boucot, 1973; Lüning et al., 2000; Lubeseder, 2005). This prograding deltaic system did not reach Morocco until the Early Devonian, where the underlying Silurian comprises a thick graptolite shale succession $(>1000 \mathrm{~m})$, only interrupted by a few, meter-thick cephalopod limestone beds (Destombes et al., 1985).

During the Early Devonian, a carbonate ramp developed in the eastern Anti-Atlas, while in the south-western Anti-Atlas (Dra Plain) mixed siliciclastic-carbonate shelf sedimentation prevailed. During the Middle Devonian, siliciclastic supply was largely switched off over much of north-west Africa, leading to widespread carbonate deposition. The Late Devonian was again dominated by shale deposition,

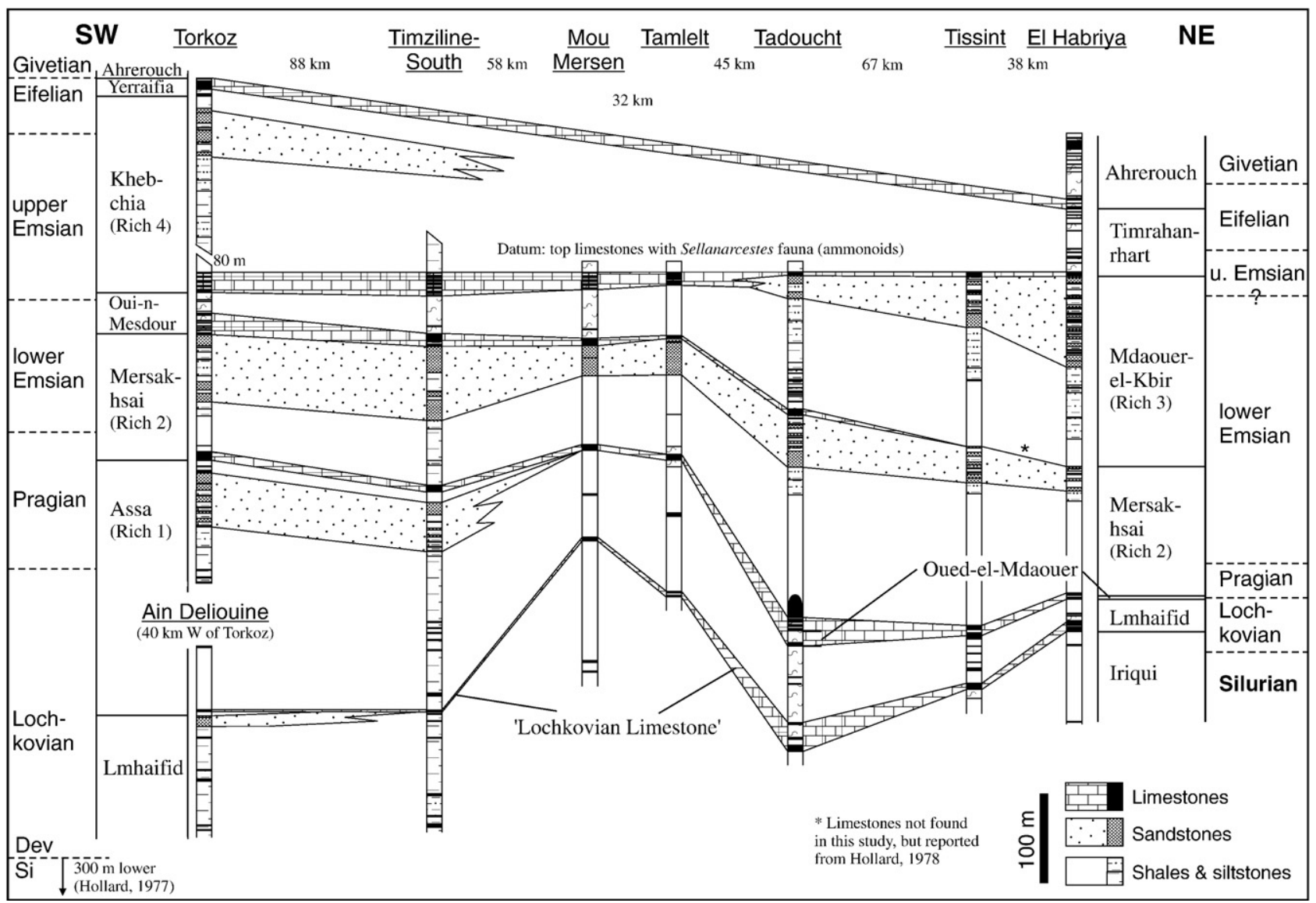

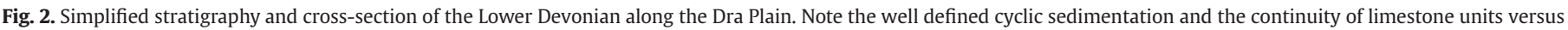
lateral sandstone distribution. 


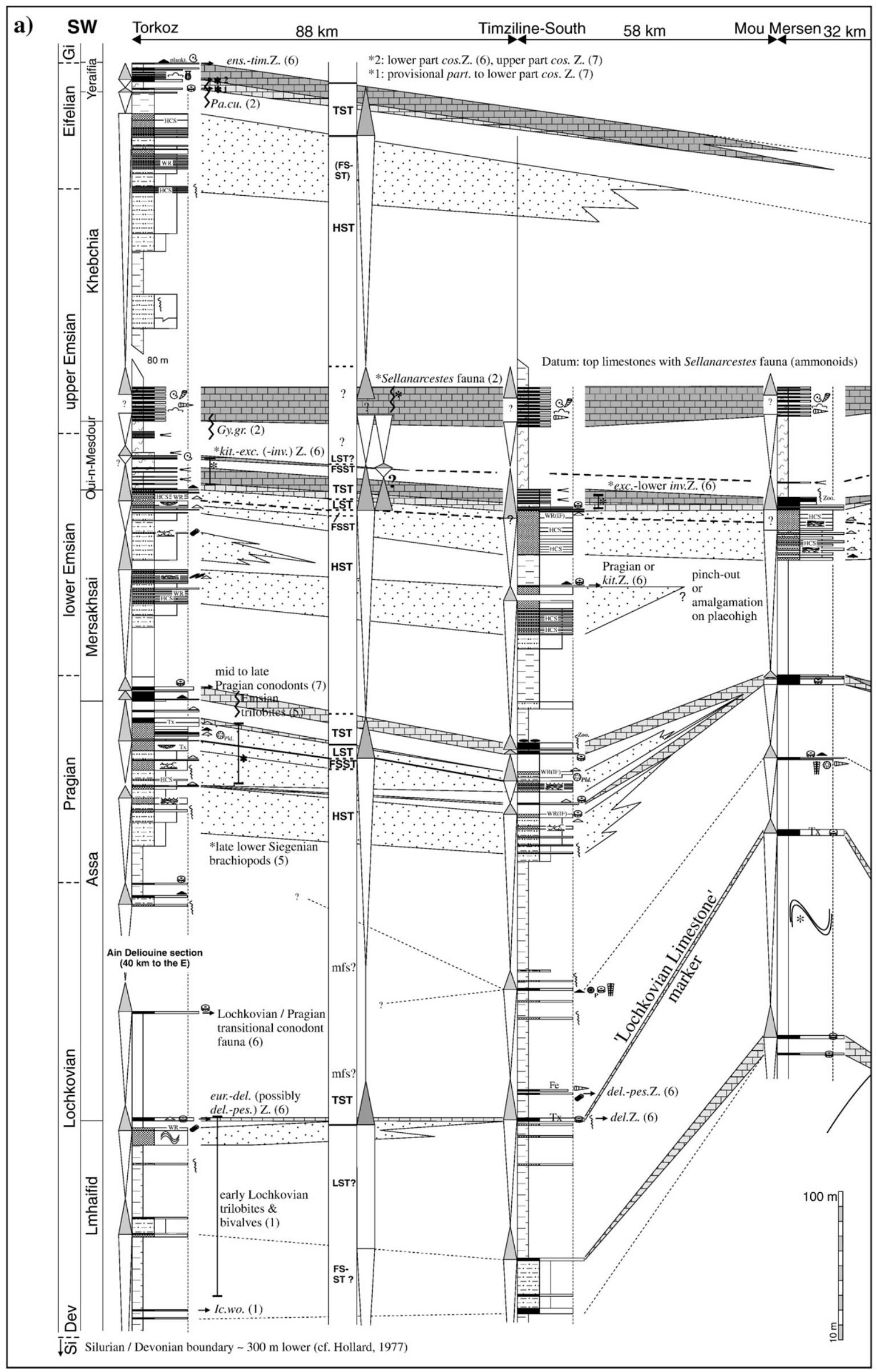

Fig. 3. Correlation of the Lower Devonian sections of the Dra Plain. See Fig. 4 for legend. 


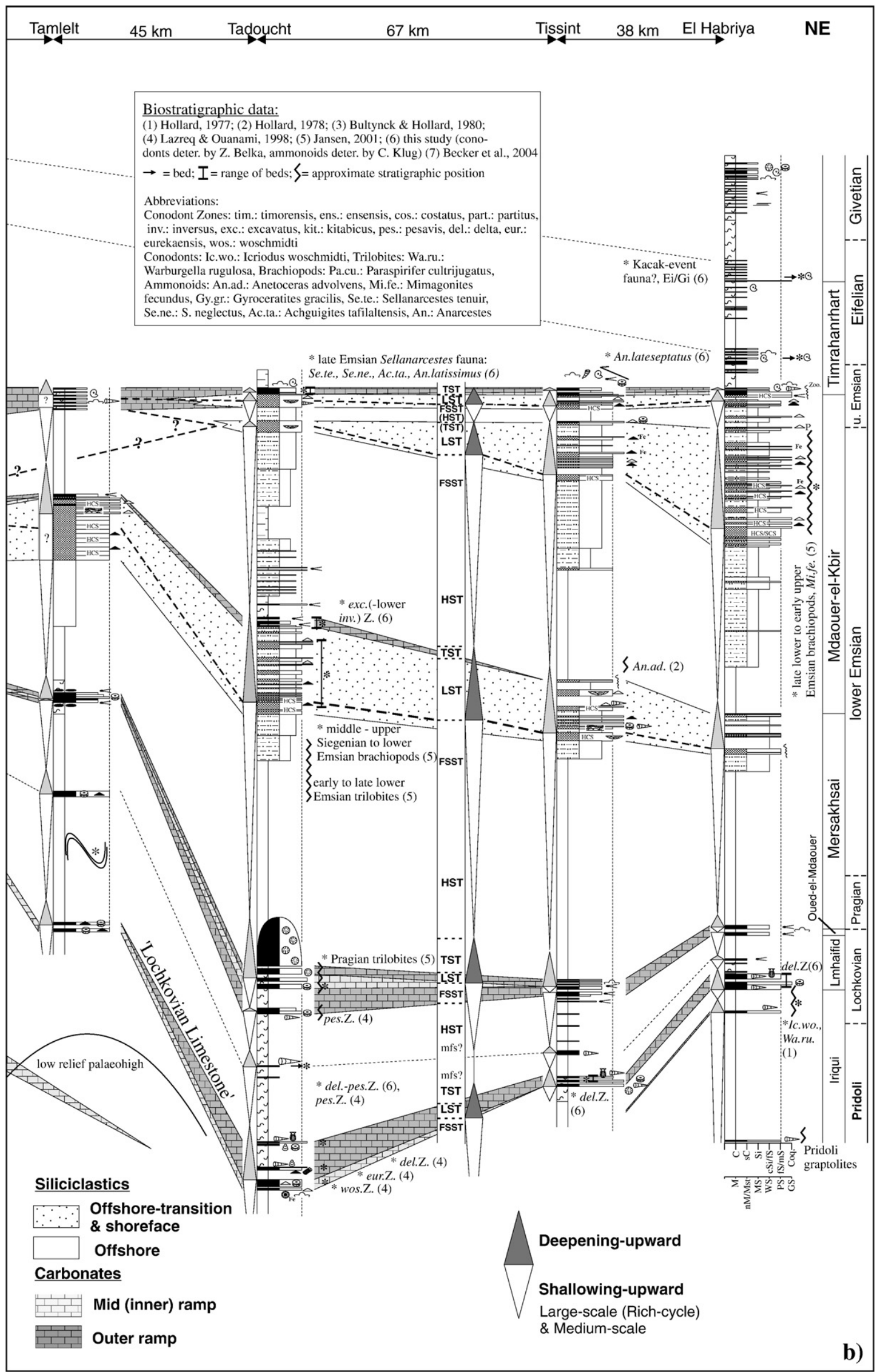

Fig. 3 (continued) 
until a marked late Famennian sea-level fall provoked rapid progradation of deltaic sandstones.

Although Silurian-Devonian limestones form an important part of the stratigraphy, carbonate production was generally low, albeit increasing steadily from the Silurian into the Middle Devonian. This increase is related to the northward movement of Gondwana into lower latitudes (e.g. Scotese and McKerrow, 1990; Stampfli and Borel, 2002; Copper, 2002) and warmer waters, combined with Silurian to Middle Devonian global warming (Frakes et al., 1992).

The palaeogeographic position during the Early Devonian, at around $40^{\circ}$ to $60^{\circ}$ south, and the low carbonate production both suggest a cool-water setting for North Africa at this time, in which typical warm-water indicators, such as stromatoporoids and calcareous ooids (James, 1997) are generally absent.

\subsection{Stratigraphic framework}

The Lower Devonian of the Dra Plain attains a thickness of more than $600 \mathrm{~m}$ and displays characteristic cyclic sedimentation of marine limestones, shales and sandstones (Fig. 2). A typical cycle consists of 10-20 m thick limestones, followed by 100-150 m thick shales and siltstones, overlain by $70-120$ m thick sandstones. Hollard (1981a) recognised four of these cycles and termed them Rich-cycle 1 to 4 . They range in age from Lochkovian/Pragian to Emsian and early Eifelian, and can be placed into an increasingly well defined biostratigraphic framework (Hollard, 1977, 1978; Bultynck and Hollard, 1980; Jansen, 2001; El Hassani, 2004; Jansen et al., 2007). To further constrain the correlation along the studied transect and age of the generated sequences, some conodont and ammonoid samples have been determined in addition during this study.

Several formations are defined by the Rich-cycles, that start at the base of a limestone unit and end at the top of the succeeding sandstone unit. However, different formations have been defined between the south-western Dra Plain and the north-eastern Dra Plain, which reflects the differing sandstone distribution between these two areas (Fig. 2). Due to the problematic definition of the Lochkovian Lmhaifid Formation, which is currently under revision (El Hassani, 2004; Jansen et al., 2007), the early Lochkovian regional limestone marker at the base of the described sections is informally named 'Lochkovian Limestone' in this study.

\section{Facies description and interpretation}

\subsection{Carbonate facies}

The limestone units form lithological and stratigraphic markers, which can be mapped and correlated throughout the Dra Plain transect (Fig. 3). They display three main lithofacies associations (FA): a) rhythmically interbedded lime mudstones and marls, b) nodular bioclastic wackestones and interbedded marls, and c) bioclastic packstones to grainstones with interbedded fossiliferous marls.

3.1.1. Outer ramp rhythmically interbedded lime mudstones and marls Interbedded lime mudstones and marls occur in packages between 10 to $30 \mathrm{~m}$ in thickness. Beds are thin to medium bedded and the interbedded marlstone beds vary in thickness from a few centimetres to 1-2 m (Fig. 5a, b). Two sub-facies associations are differentiated. The first comprises dark-grey to black lime mudstones with occasional Zoophycos burrows. Some levels are characterised by frequent debris of tentaculitids (Oui-n-Mesdour Formation), while others contain abundant small, pyritised cephalopods (Timrhanrhart Formation). The second type comprises light-grey lime mudstones with frequent trilobites, cephalopods and solitary rugose corals. The interbedded marls in this facies can be silty and the mudstones characteristically weather to a yellowish colour (e.g. lower Khebchia Formation limestones, Fig. 5a).

Interpretation: The limestones display characteristics that indicate deposition in a low-energy environment below storm wave-base, as shown by their hemi-pelagic faunal content and texture. The micritic fraction of this facies is interpreted to have been mainly supplied by suspension clouds derived from storm reworking in shallower waters (mid-ramp). In similar mudstone/marl alternations of the Middle Devonian in the eastern Anti-Atlas, individual micritic grains are visible in slightly coarser lime mudstone beds. These reworked lithic peloids are thought to be the main source for the micritic fraction of

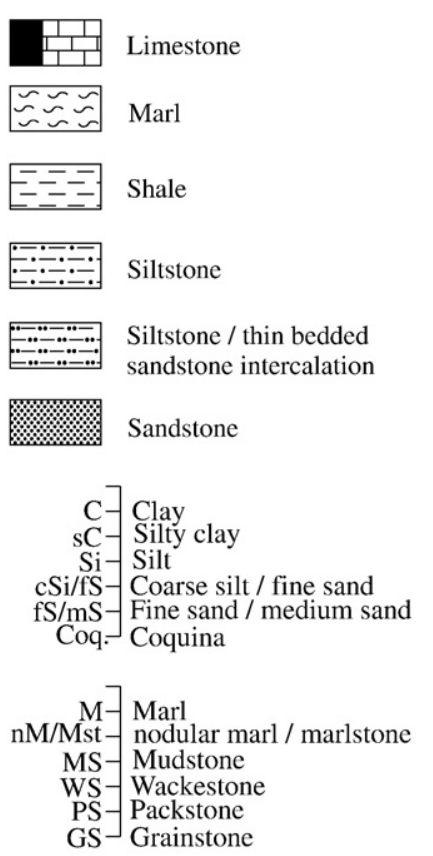

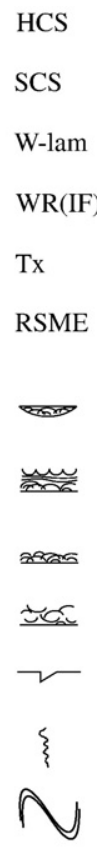

Hummocky cross-stratification

Swaley cross-stratification

-lam Wavey lamination

R(IF) Wave ripples (interference)

Trough cross-bedding

Regressive surface of marine erosion

Coquina pockets

Coquina, HCS to low-angle cross stratification, wave ripples

Coquina

Shelly sandstone

Flute marks

Bioturbation (Zoo.: Zoophycos)

$\mathrm{x} 1 \mathrm{~m}$ to $\times 10 \mathrm{~m}$ folding and uncertain thicknesses and number of beds

\begin{tabular}{|c|c|}
\hline$\Delta \Delta$ & $\begin{array}{l}\text { Brachiopods (whole-skeleton; debris } \\
\text { in siliciclastic / calcareous matrix) }\end{array}$ \\
\hline 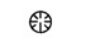 & Corals (Pld.: Pleurodictyum) \\
\hline$\theta$ & Solitary rugose corals \\
\hline (0) & $\begin{array}{l}\text { Iron-oolites, phosphatic pellets, } \\
\text { coated grains }\end{array}$ \\
\hline 30 & Crinoids, crinoid stems \\
\hline 8 & Gastropods \\
\hline 㺷 & Bryozoans \\
\hline 8 & Bivalves \\
\hline$m$ & Trilobites \\
\hline$\infty$ & Orthocone nautiloids \\
\hline$\odot$ & Ammonoids \\
\hline$<$ & Tentaculitids \\
\hline
\end{tabular}

Fig. 4. Legend for Figs. 3, 6 and 7. 

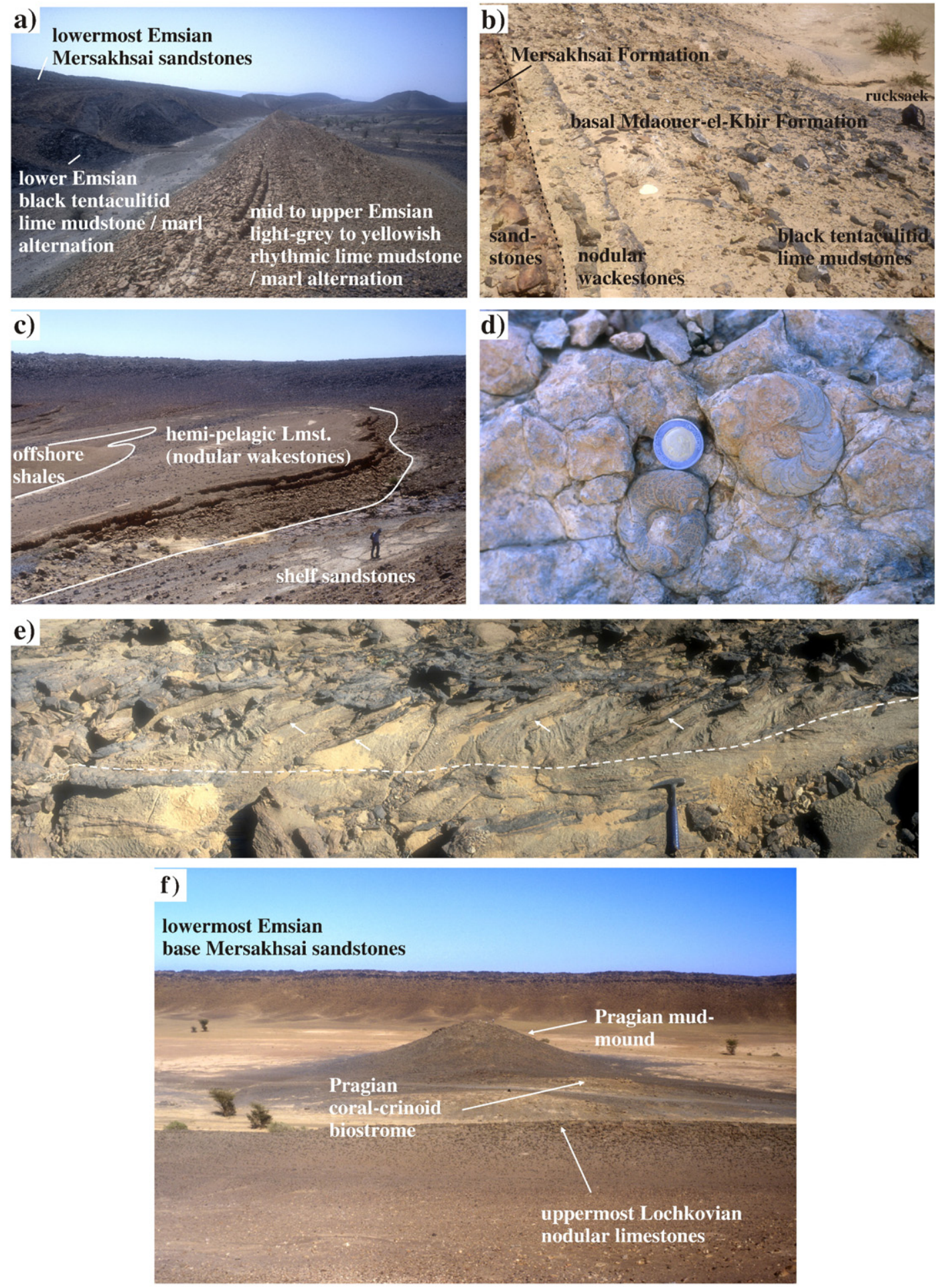

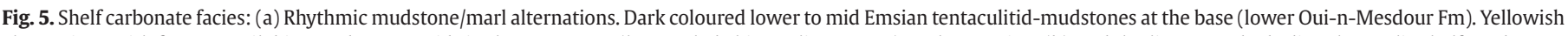

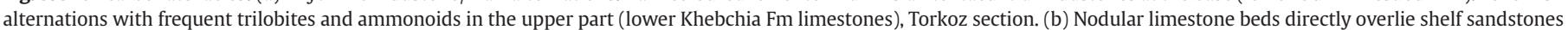

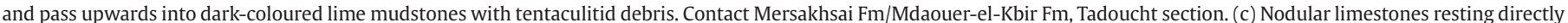

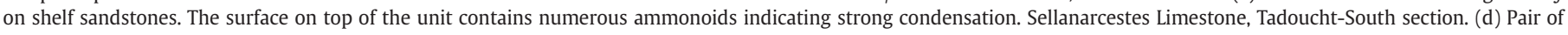

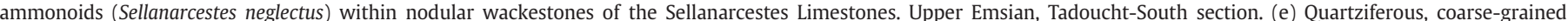

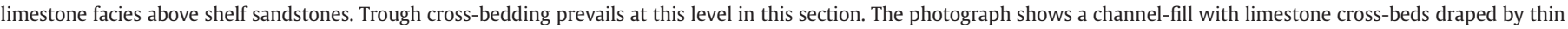
sandstone layers (in dark). Uppermost Assa Formation, Torkoz section. (f) Pragian mud-mound of the Tadoucht section.

the Devonian hemi-pelagic carbonates in North Africa in analogue to the depositional-diagenetic lime mudstone model of Coniglio and James (1990), despite the fact that the lithic peloids in most cases are difficult to identify due to subsequent bioturbation and a strong micro- to pseudosparitisation. The lack of calcareous nano-plankton in the Palaeozoic, that normally provides pelagic carbonate production, means the bulk of the carbonate material in the distal environments is interpreted as allochthon. The hemi-pelagic fauna in 
this association (e.g. ammonoids, planktonic tentaculitids, ostracods) are thought to have added relatively small amounts of carbonate to the gross volume.

\subsubsection{Outer ramp nodular bioclastic wackestones}

Nodular bioclastic wackestones occur in thin packages of 1-5 m thickness (Fig. 5c). Beds are thinly to medium bedded, but very often individual beds cannot be discerned. The limestones are light-grey in colour and contain a macrofauna comprising frequent cephalopods and trilobites (Fig. 5d). On a microscopic scale, tentaculitids and ostracods usually dominate over debris of bryozoans, crinoids, brachiopods, bivalves, gastropods and corals. In transition to bioclastic packstones, the abundance of tentaculitids and crinoid debris increases.

Interpretation: This facies is also interpreted to have been deposited in an outer ramp environment below storm-wave base. The nodular fabric and the thin to absent marly interbeds suggest lower sedimentation or preservation rates than in the rhythmic mudstone/marl facies association, which may have originated from less sediment input or secondary increased winnowing by shelf currents.

\subsubsection{Mid ramp bioclastic packstone to grainstone blankets and shoals}

Bioclastic packstones to grainstones appear in 5-10 m thick units and are dominated by brachiopod and crinoid debris. The facies is often transitional into either tentaculitid pack- to wackestones or quartziferous brachiopod-coquinas. The limestones are massive, medium to thickly bedded and light-grey in colour. Sedimentary structures are rare and only occasionally is remnant cross-bedding observed. Thin sections show a remarkable densely packed texture of bioclasts.

Some locations deviate from the general massive appearance and display trough cross-bedding throughout entire limestone units (Lochkovian Limestone of the Mou Mersen and Timziline sections, Fig. 3). A trough cross-bedded limestone is particularly well developed in the uppermost part of the Assa Formation in the Torkoz section. Here, quartziferous brachiopod-crinoid-limestones are intensely interbedded with fossiliferous sandstones. Larger troughs are in-filled with limestone cross-beds, each capped by a thin sandstone veneer (Fig. 5e).

Interpretation: Most limestones of this facies association display characteristics suggesting deposition above storm wave-base, within a mid-ramp hydrodynamic zone (e.g. Burchette and Wright, 1992). A trend towards shallower waters is recognised by a faunal change from tentaculitid to crinoid to brachiopod dominated sediments.

Unequivocal high-energy conditions are only recorded by the trough cross-bedded limestones. The Lochkovian Limestone of the Mou Mersen area is interpreted as a distal shoal, which passes laterally into mid-ramp skeletal blankets. The quartziferous limestones of the uppermost Assa Formation in the Torkoz section directly overlies a thick sandstone package. The vertical facies transition suggests nearshore (upper shoreface) environments in this case. Larger troughs in this unit may indicate tidal channelling.

\subsubsection{Other facies associations: earliest Devonian cephalopod limestones and mud-mounds \\ Two further facies types are found, which however are stratigra- phically limited to one formation and/or are of local extent. The Lochkovian interval contains black orthocone nautiloid and scyphocri- noid (planktonic Crinoidea) limestones in the north-eastern Dra Plain and form the up to $10 \mathrm{~m}$ thick 'Lochkovian Limestone' in this region.}

This peculiar low-oxygen outer ramp facies is limited to the Silurian and Lochkovian, after which the basinal environment became much more oxidized (Kriz, 2000; Lubeseder, 2008).

During the Pragian a small mud-mound with common corals developed in the central Dra Plain (Tadoucht section) overlying a crinoid-coral biostrome (Fig. 5f). The mound is interpreted to have formed close to the outer to mid ramp transition.

\subsubsection{Carbonate shallowing/deepening cycles}

In the studied sections, the limestone units often reveal either a midramp facies or an outer-ramp facies, and vertical passage from the one association into the other is limited to thin transition zones. Shallowing/deepening trends within the same facies association are recognised, indicated for example by the presence of intercalated siltstones in the mid-ramp, bed thinning/thickening, increase/decrease in the thickness of interbedded marlstone, but most importantly by changes in the biofacies (e.g. brachiopod/crinoid dominated vs. ammonoid/trilobite/tentaculitid dominated). Most limestone units show thick deepening-upward facies, and shallowing-upward trends are thin or absent, which gives the carbonate cycles a strong asymmetry.

\subsection{Siliciclastic facies}

In contrast to the limestones, the Dra Plain siliciclastics rarely extend across the entire transect and commonly pinch out laterally. The facies associations and lithofacies stacking patterns also differ across the Dra Plain and can be lumped into two types, one occurring in the south-west and the other in the north-east:

In the south-west, the siliciclastics comprise 130- $270 \mathrm{~m}$ thick coarsening-upward (CU) intervals, which are subdivided into two or three higher-order cycles (20-70 m thick) (Figs. 3 and 6). In the upper part, relatively thin (2-20 m) and less well defined fining-upward (FU) intervals are identified below the capping Rich-limestones.

In the north-east, CU-intervals are less gradational, with higherorder cycles being less well developed or absent. However, in the upper part of the siliciclastics, FU-intervals are thicker $(40-70 \mathrm{~m})$ consisting of a number of metre-scale cycles (Figs. 3 and 7).

The observed siliciclastic facies can readily be interpreted using existing shelf sedimentation and shoreline succession models (e.g. Walker and Plint, 1992; Reading, 1996; Hampson and Storms, 2003).

\subsubsection{Offshore shales and siltstones}

Greenish shales and siltstones make the lower, 70-150 m thick part of the Rich-clastics. Intercalations of thinly bedded sandstones displaying bioturbation, scour marks and ripple-cross lamination are present and become frequent in the upper part of these units. Some of the siltstone beds are enriched in tentaculitids and pure tentaculitid layers have been found ranging in thickness from millimetres to a few centimetres (lower Mdaouer-el-Kbir Formation of the Tadoucht section). From the upper part of the Mersakhsai Formation siltstones and thinly bedded sandstones, trilobites and brachiopods have been reported (Schraut, 2000; Jansen, 2001).

Interpretation: The facies is typical for offshore environments with intercalated distal storm-deposits or storm-generated turbidite beds.

\subsubsection{Storm-dominated offshore-transition silt- and sandstones in CU- intervals \\ The shales and siltstones grade into rhythmically interbedded medium bedded sandstones and siltstones in the south-western Dra Plain (Torkoz and Timziline sections). Many sandstones are brachiopod- rich and frequently contain coquinas. Sedimentary structures include}

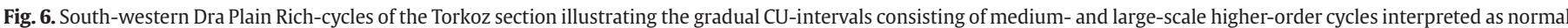

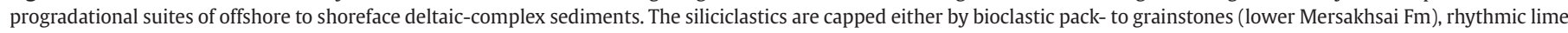

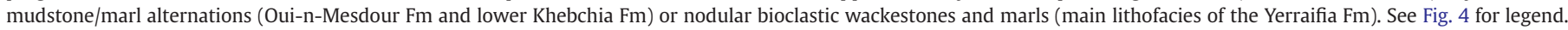



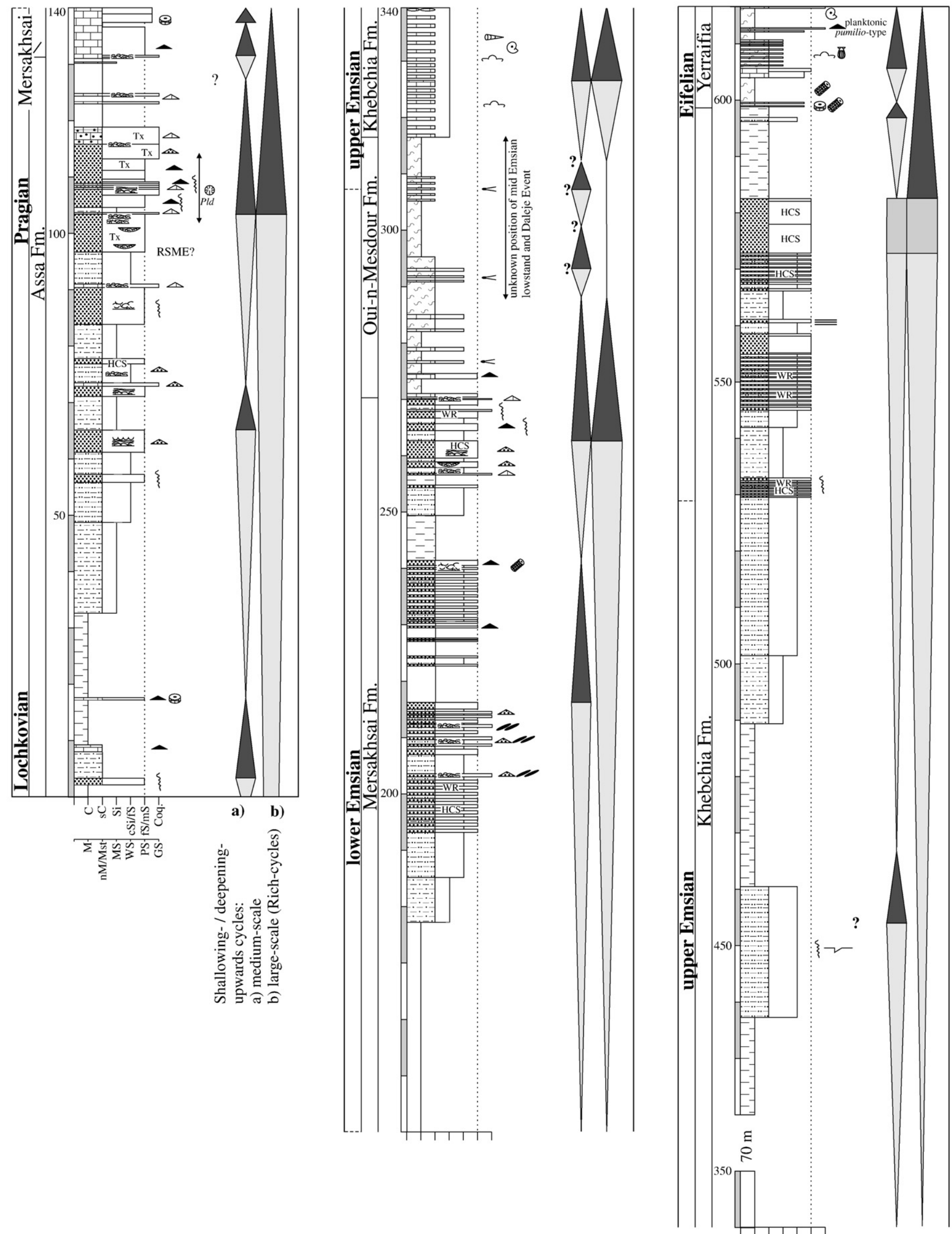
hummocky cross-stratification (HCS), gutter casts and wave-ripples, all of which can be found within one bed. Occasionally intraclasts are imbricated in the brachiopod-coquinas.

Interpretation: The facies is typical for a storm-dominated offshore-transition zone above storm-wave base. The siltstones and sandstones form higher-order shallowing-upward cycles, some of which are overlain by a $10-20 \mathrm{~cm}$ thick brachiopod-crinoid limestone bed; and thus display a cycle-type identical to the lower-order Richcycles.

\subsubsection{Lower shoreface and rip-current channel sandstones}

In the upper part of the Rich-siliciclastics in the south-western Dra Plain, the interbedded sandstones, siltstones and coquinas eventually grade into thickly bedded HCS-sandstones or massive sandstones with small pockets of brachiopod-coquinas. Rarely, metre-scale scour and fill structures cut into the underlying facies association (Assa Formation of the Timziline-North section, Fig. 8a). The scours are filled with fine to medium grained, ripple cross-laminated and trough cross-bedded sandstones.

Interpretation: The facies association shows typical features of a lower shoreface depositional environment, in which storm-beds are amalgamated. Amalgamation has resulted in discontinuous coquinas, in the form of small erosional remnant lenses. These can be compared to the tens to hundreds of metres long continuous coquina beds found in the offshore-transition zone FA, effected by less amalgamation.

The scour and fill structures are interpreted as rip-current channels, which cut into the lower shoreface and offshore transition zone deposits.

\subsubsection{Upper shoreface sandstones and calcareous sandstones}

The Rich-cycle CU-intervals of the south-western Dra Plain usually end with the thickly bedded HCS-sandstones. In the Assa Formation of the Torkoz section, however, sandstones in the uppermost part are trough cross-bedded. These are directly overlain by an intensely crossbedded unit of calcareous sandstones and quartziferous brachiopodlimestones (Fig. 5e).

Interpretation: This facies association is interpreted as upper shoreface deposits and is the shallowest facies observed in the Dra Plain sections. Notably, it has been found only in one formation and at one location.

\subsubsection{Distally amalgamated storm sandstones}

This FA is exposed in the north-eastern Dra Plain, where it more or less directly overlies the lower Rich-cycle shales and siltstones and forms the basal sandstone package of the Rich-sandstones (Tadoucht, Tissint, and El Habriya sections). These are thickly bedded sandstones displaying large-scale hummocks and swales, and subordinate siltstone intercalations (Fig. 8b,c). In areas where the Rich-sandstones pinch out (Mdaouer-el-Kbir Formation in the Tadoucht section and area, Fig. 3) or become very reduced in thickness (Mersakhsai Formation in the El Habriya section, Fig. 3), the FA passes laterally into massive, medium to thickly bedded sandstones. Sedimentary structures are limited to a few small brachiopod-coquina lenses and rare bioturbation. In addition to a few brachiopods, orthocone nautiloids, corals and crinoid debris may be present.

Interpretation: In bed thickness, degree of amalgamation and sedimentary structures, the HCS-sandstones resemble lower shoreface deposits. However, the lateral facies relationship to massive sandstones with rare hemi-pelagic faunas (orthocone nautiloids) suggests these sandstones may have been amalgamated below fair weather wave-base within the offshore transition zone. This interpretation is supported by the fact that the sandstones pass laterally into silty lime mudstones, which were clearly deposited below stormwave base (transition Mdaouer-el-Kbir sandstones into Sellanarcestes Limestone in the larger Tadoucht region). This suggests significant amalgamation took place within an offshore-transition zone. Notably, all of these thick bedded sandstones are fine grained and could have been amalgamated from thinly bedded distal storm deposits by successive reworking and removal of the silt fraction.

\subsubsection{Storm-dominated offshore-transition silt- and sandstones in FU- intervals}

This FA rests above the thickly bedded HCS-sandstones in the southwestern Dra Plain, forming units between 2-20 m thick. It is similar to the interbedded sandstone, siltstone and coquina FA below the main Rich-cycle sandstones in that hummocky cross-stratification and brachiopod-coquinas are common. However, a rhythmic bedding style is not developed and common interference wave-ripples are present (Fig. 8d). In addition, brachiopod-shell layers tend to be more calcareous, forming quartziferous limestone-coquinas. A characteristic feature are bedding surfaces enriched in iron and the presence of articulated whole brachiopod shells. Pleurodictyum corals have been found on these surfaces (Fig. 8e) and thin sections show abundant ironstained, glauconitised peloids.

The FA is particularly well developed in the north-eastern Dra Plain, where it also rests on thickly bedded HCS-sandstones. Here, 40-70 m thick fining-upward units display a cyclic alternation of siltstones, HCS-sandstones, brachiopod-rich sandstones and brachiopod-coquinas (Figs. 7 and 9). In common with the southwestern Dra Plain sections, many cycles end with iron-enriched surfaces with numerous articulated brachiopod shells (Fig. 8g). Interference wave-rippled sandstones and Pleurodictyum corals were not observed however.

Interpretation: The facies suggests deposition within a stormdominated offshore-transition zone, but in contrast to the facies equivalent in the $\mathrm{CU}$-intervals, sedimentation-breaks are indicated by the iron-enriched flooding surfaces with intact, articulated brachiopod shells. Such breaks are also indicated by the Pleurodictyum corals, which have been taken as a typical example of a firm substrate (hardground) community (Taylor and Wilson, 2003).

Compared to the south-western Dra Plain, the facies in the northeast suggests deposition in slightly deeper water, with greater accommodation space, as is evidenced by a much better defined bedding style, thicker siltstone intercalations, higher continuity of beds and the lack(?) of wave-ripples.

\subsubsection{Siliciclastic shallowing/deepening cycles}

In the south-west, the CU-intervals with their higher-order cycles, show a progradational stacking pattern of facies associations typical for a suite of pro-delta deposits passing through offshore-transition zone storm-deposits into lower shoreface sandstones. The studied sections did not contain sedimentary structures suggestive of environments shallower than the shoreface. Only in one section and formation (Assa Formation, Torkoz section), the upper shoreface is reached.

In the north-eastern Dra Plain, the CU-intervals show a much less gradational shallowing in the lower parts and a more abruptregressive relationship, with thickly bedded, amalgamated stormdeposits resting on offshore shales and siltstones.

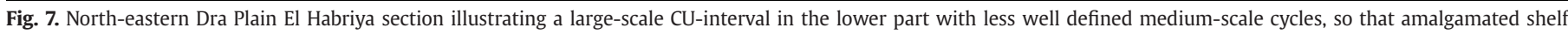

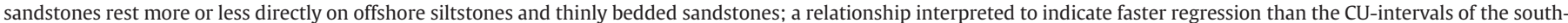

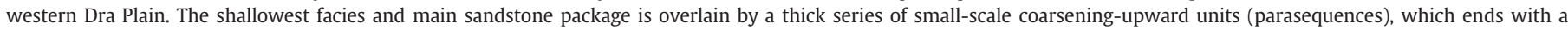

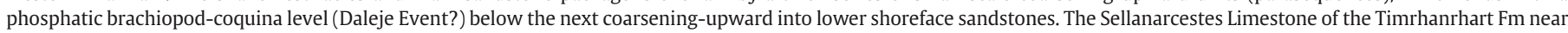
the top of the section grades rapidly from quartziferous brachiopod grainstones into nodular wackestones with cephalopods and trilobites. See Fig. 4 for legend.
} 

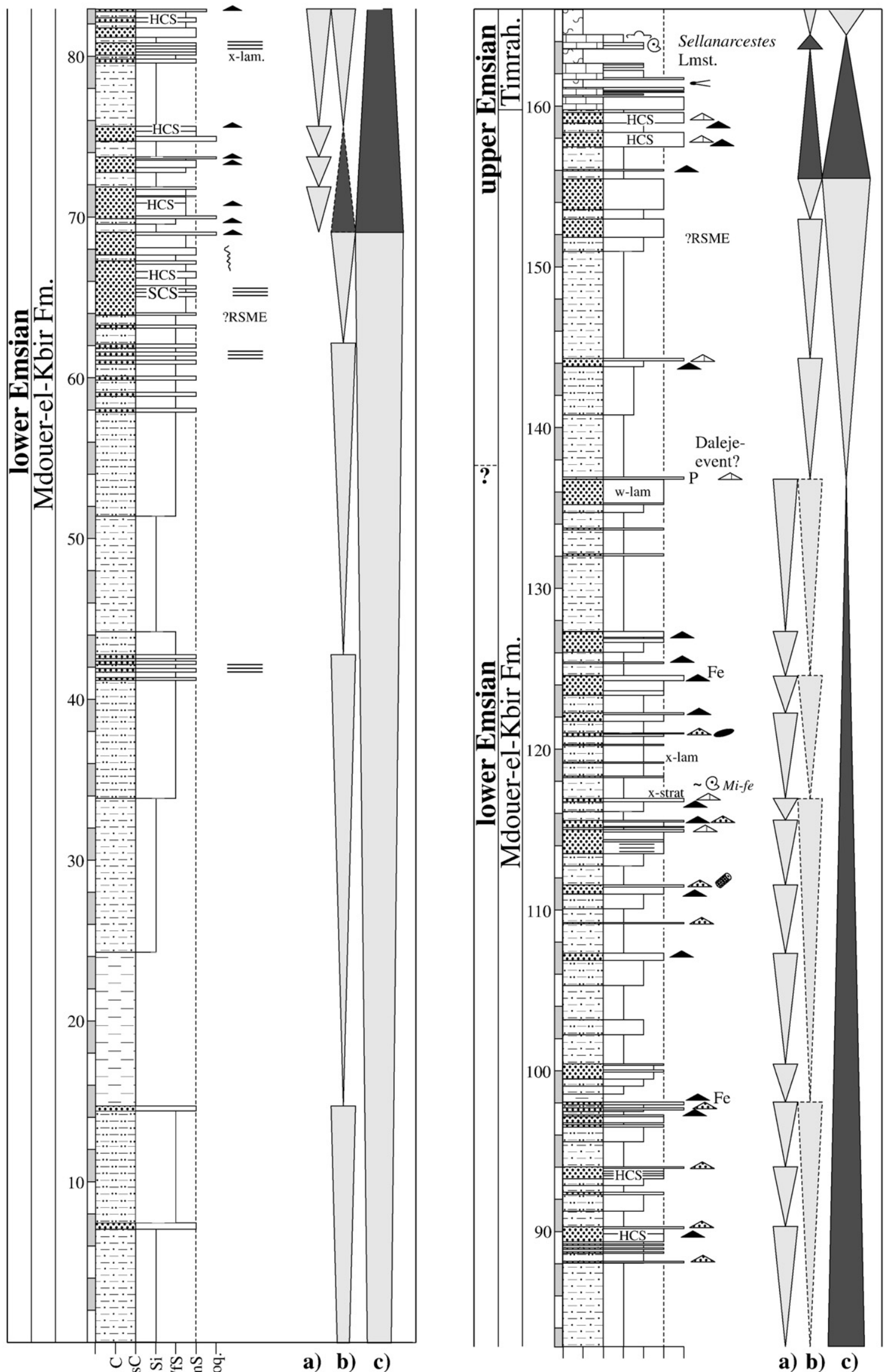

\footnotetext{
a) b) c)

Shallowing- / deepening-upwards cycles:

$\sum \sum_{i=1}^{n} \sum_{i}^{n} \dot{n} \hat{n}$

a) small-scale (parasequences), b) medium-scale

c) large-scale (Rich-cycles)
}

a) b) c) 

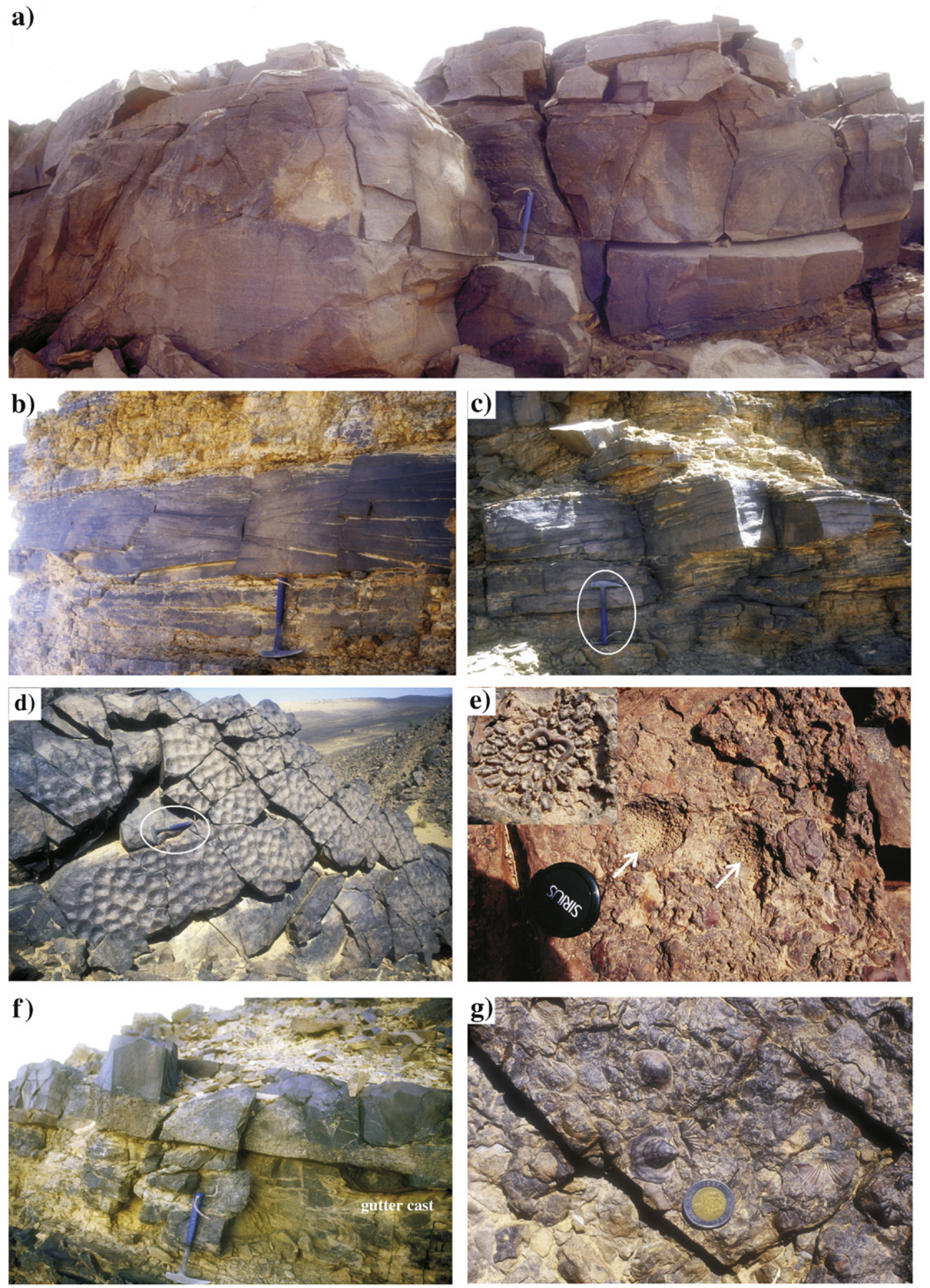

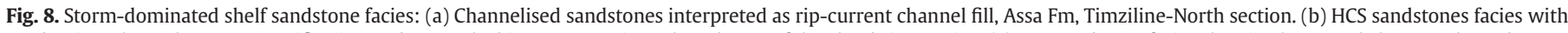

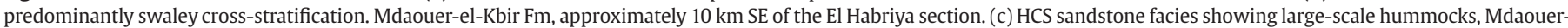

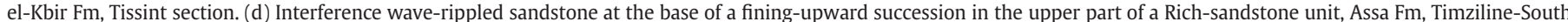

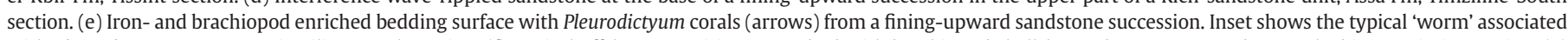

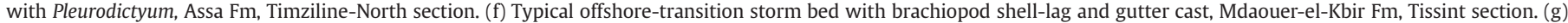
Iron- and brachiopod-enriched bedding surface of a small-scale cycle (parasequence) from a fining-upward sandstone successions, Mdaouer-el-Kbir Fm, El Habriya section.

The succeeding FU-intervals show poorly defined higher-order cycles in the south-west, but very well developed, aggradationally to retrogradationally stacked higher-order cycles in the north-eastern Dra Plain. In both areas, the intervals record an overall deepening- upward trend, which becomes most evident from the increasingly calcareous character of the intercalated brachiopod-coquinas and the marked flooding surfaces, but also from diminishing sandstone content and increasing interbedded siltstone thicknesses. 


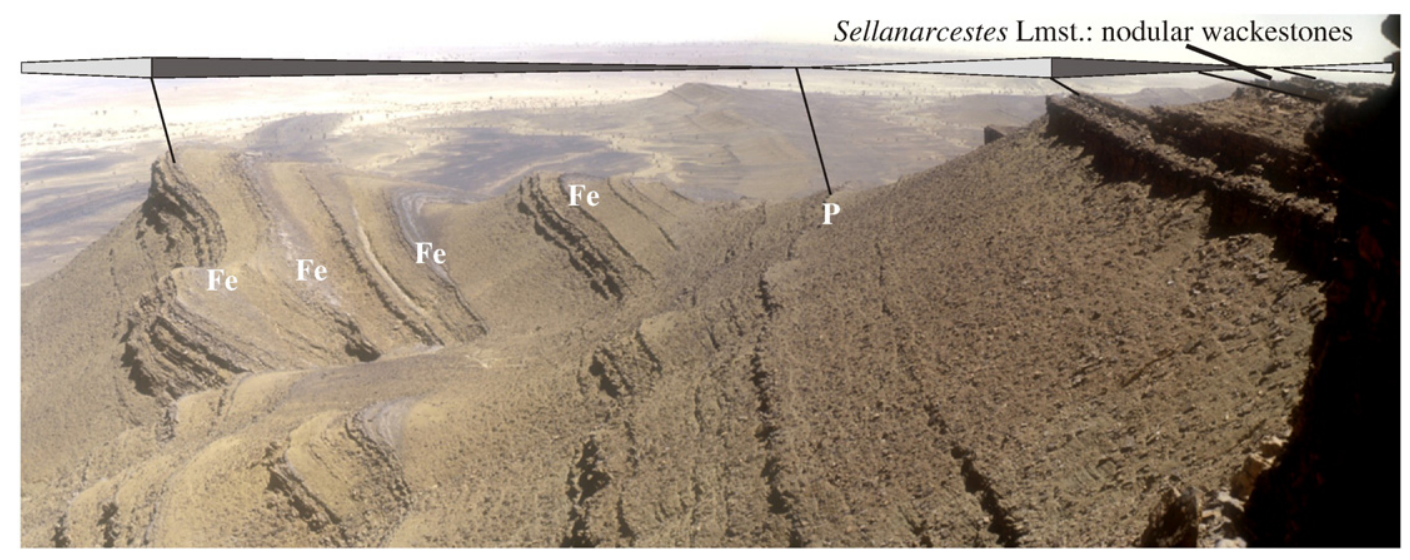

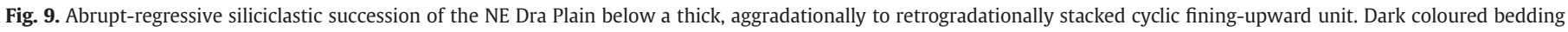

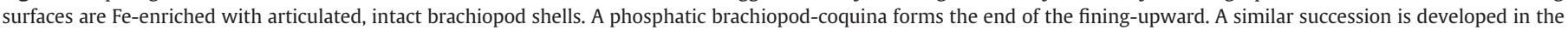

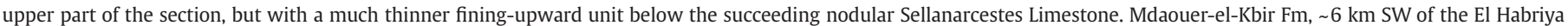
section.

\subsection{Lateral correlation and palaeogeography (Rich-cycles)}

\subsubsection{Correlation and proximal distal-trends}

The presence of distinct Rich-cycle limestones enable lithological correlation over the entire transect. Most of these correlations are confirmed by published biostratigraphic data (see references in Fig. 3). Some additional conodont samples have been analysed during this study to increase confidence in correlation and further constrain sequence ages. The most important literature-derived data, together with the sections dated in this study, are plotted onto Fig. 3.

A regional, gentle deepening trend from the south-western to the north-eastern Dra Plain is observed in almost all formations. The siliciclastics of the Lmhaifid, Assa, and Khebchia Formation all pinch out to the north-east in the central Dra Plain. The Mersakhsai Formation sandstones extend across the entire transect, but the FAs and stacking patterns to the north-east suggest deposition in a deeper shelf environment than those of the south-west. The Mdaouer-el-Kbir Formation sandstones show a notable counter trend, being restricted to the north-east and pinching out to the south-west, indicating shallower environments in the north-east at this time.

The overlying limestone units show a gradual lateral facies change from mid-ramp limestones in the south-west to outer ramp facies in the north-east. In the case of the 'Lochkovian Limestone', crinoidbrachiopod grainstones pass into an oxygen deficient outer ramp facies of black orthocone nautiloid limestones (Lubeseder, 2008). The basal Mersakhsai Formation crinoid-brachiopod grainstones interfinger with nodular wackestones in the north-east. The mudmound of the Tadoucht section is located in the mid to outer ramp transition. At the base of the Oui-n-Mesdour and Yerraifia Formation, thin mid-ramp FAs are present in the south-west, but the lateral equivalent limestone intervals in the north-east consists of outer ramp lithotypes only.

\subsubsection{Shoreline orientation and provenance}

The palaeogeography and the location of the Early Devonian shoreline is not yet well established. A southerly located shoreline that approximately ran west-east can be inferred from mapping the Mdaouer-el-Kbir Formation sandstones. In the Tata area, these sandstones reduce to about $1 \mathrm{~m}$ thickness towards the north-east (sections to the east and north of Tadoucht). In the central Dra Plain the sandstones are present in the south (Jebel Mersakhsai, Fig. 1, Hollard, 1967, 1981a,b), but are absent in the north (Mou Mersen section). This suggests a southerly provenance of the Dra Plain siliciclastics, and corresponds to the general proximal (S-SW) to distal (N-NE) trend observed across North Africa (Berry and Boucot, 1973; Lubeseder, 2005). A similar depositional pattern is seen, for example, in the distribution of terrigenous material between the Dra Plain, the eastern Anti-Atlas, and the Ougarta Arch in Algeria (Fig. 10). This indicates that the transect of the Dra Plain was orientated more or less parallel to slightly oblique to a shoreline located in the south in the Tindouf Basin (gentle deepening to the NE).

\subsubsection{Central Dra Plain palaeohigh}

A low-relief palaeohigh is interpreted to have been located in the central Dra Plain (evident in the Mou Mersen to Tamlelt sections). This is suggested by the presence of the shallowest carbonate facies in this region, comprising intensely trough cross-bedded limestones deposited within a distal shoal during the Lochkovian. The area is in addition characterised by a generally reduced section thickness (Fig. 3). A gentle palaeohigh in the central Dra Plain is also recognised from facies mapping of Silurian limestones, where however the high was located further to the north-east in the Tadoucht (Tata) region (Lubeseder, 2008).

The existence of the palaeohigh and the approximately shorelineparallel orientation of the Dra Plain transect effects the correlation of higher-order siliciclastic coarsening-upward cycles. In the Assa and Mersakhsai Formation of the south-west, such cycles are correlated stratiform and are interpreted to pinch out onto the palaeohigh where they were eroded, by-passed or amalgamated with the overlying sandstones. This interpretation obviously differs from shorelinenormal transects, where these units would have been correlated in a progradational sense down-lapping onto the basin-floor.

\subsubsection{Switching of delta-complexes}

The south-western Dra Plain was the site of increased terrigenous supply and deposition of thick pro-delta shales, siltstones, and stormdominated sandstones. In the north-eastern Dra Plain, reduced sedimentation resulted in deposition of thin outer ramp limestone units. This trend reversed during the deposition of the Mdaouer-elKbir Formation sandstones. Extending the cross-section from the base of the Silurian up to the top of the Middle Devonian, shows that the north-eastern Dra Plain was also the site of increased terrigenous supply during other times (Fig. 11). From this extended correlation it becomes apparent that siliciclastic depocentres (characterised by thick graptolite shale intervals in the Silurian) switched in a surprisingly regular pattern between the south-west and the northeast. Each siliciclastic depositional phase in one area was opposed by starvation and limestone deposition in the other area. Only in two examples, the amount of terrigenous supply was more evenly distributed across the Dra Plain (Pridoli and lower Emsian). Notably a depocentre was never located in the central Dra Plain in the area of the palaeohigh. 


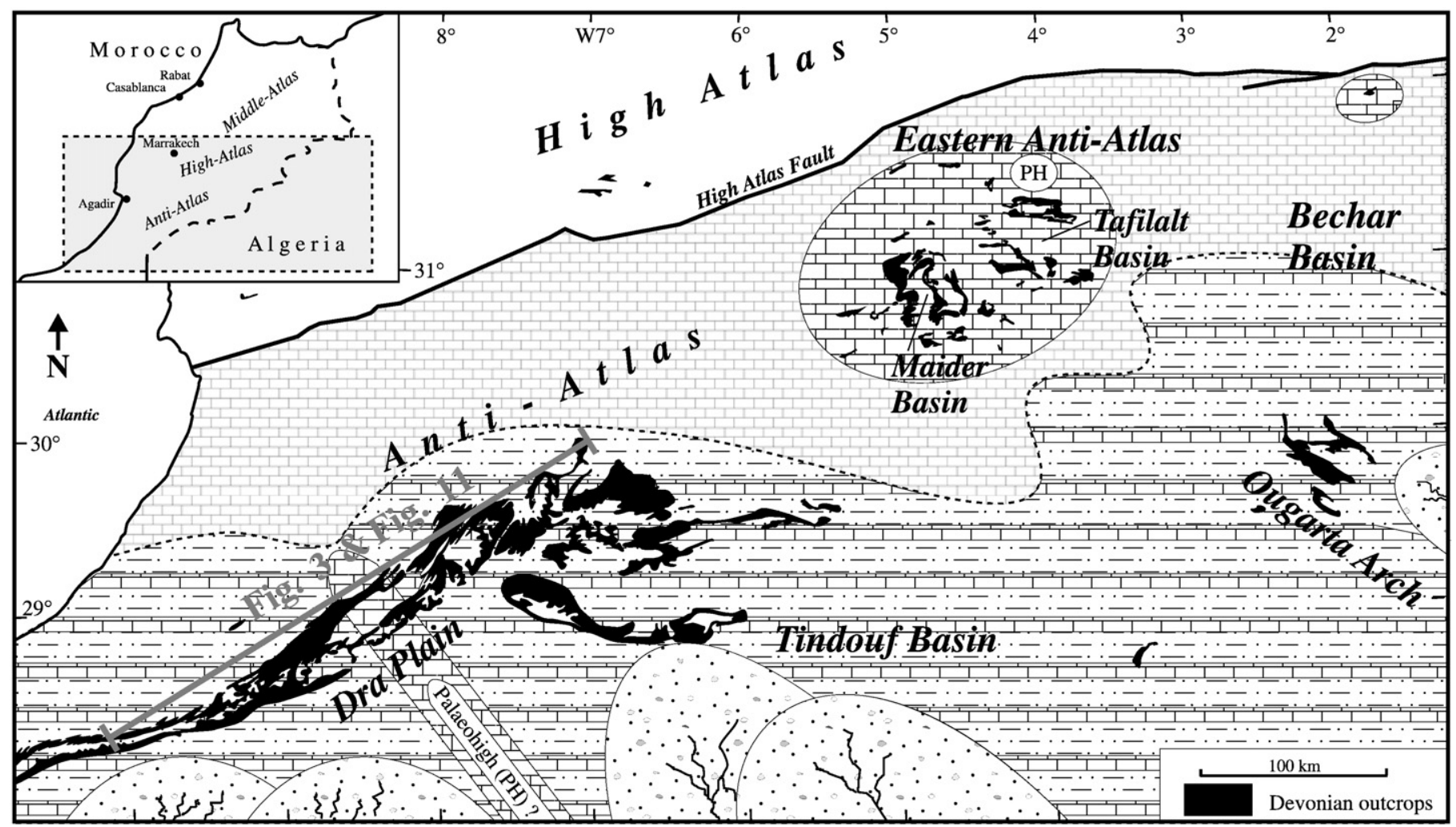

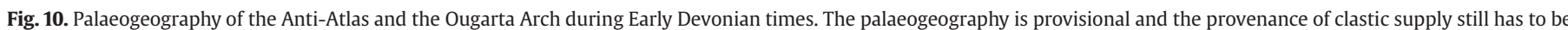

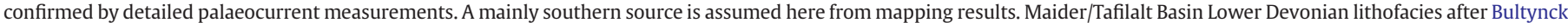
and Walliser (2000); Ougarta Arch lithofacies after Boumendjel et al. (1997).

The switching depocentres could be explained by long-term shift and abandonment of large deltaic complexes prograding from the south. Unfortunately little is known about the probable source area, the Tindouf Basin to the south, where few petroleum wells have been drilled. The palaeohigh recognised in the central Dra Plain may have extended south into the basin and may have hindered delta progradation along its strike. The cause of the switching is most likely related to the interplay of basin-fill (accommodation loss) and subsidence and the lateral (spatial) distribution of clastic input therefore has a strong autocyclic component. The temporal distribution and time of basin-fill, however, is thought to result from eustatic sea-level falls (see discussion below).

\section{Discussion}

\subsection{Mixed siliciclastic-carbonate shelf sequences}

The studied sequences share many similarities with other intracratonic to marginal cratonic sequences of the Devonian in, for example, the Timimoun Basin in Algeria and the Ghadames Basin in Libya (Lubeseder, 2005). These sequences are typified by their large continuity and the lack of pronounced breaks in the depositional profile and consequently are best explained with ramp models. The above discussion showed however, that the ramps were intersected by palaeohighs and therefore were not homoclinal. Further, some distally steepened transects may be expected.

Sequence stratigraphic ramp models have subdivided the former highstand systems tract into a gradual outbuilding phase (progradational highstand systems tract, HST) followed by a more rapid regression during relative sea-level fall (falling stage systems tract, FSST) (Plint and Nummedal, 2000). Because of the rapid regression, shoreface sandstones rest directly above offshore deposits in the more distal ramp. With the start of relative sea-level rise, sediment is still supplied to the distal ramp location forming a progradationally to aggradationally stacked lowstand systems tract (LST). These thin upgradient towards a subaerial unconformity and are detached from basin margin deposits. Sediments of the transgressive systems tract (TST) retrograde quickly on ramps and form thin units on the basin margin, which are absent in the distal ramp.

The different stacking-patters and facies observed between the south-western and the north-eastern Dra Plain can be explained using these depositional sequence stratigraphic ramp models, even though precise time-line correlation is difficult due to the shoreline parallel cross-section. The carbonates of the Rich-cycles have been integrated into a mixed shelf model (Fig. 12), based on a palinspastic reconstruction that considers the south-western Dra Plain to represent a proximal ramp location and the north-eastern Dra Plain to represent a distal ramp location. Outer ramp to basinal carbonates are plotted in the most down-gradient location, although in the actual Dra Plain transect they were largely deposited adjacent to the switching delta-lobes, not down-gradient. Notably, the model does not enter the littoral realm.

\subsection{Dra Plain sequences}

\subsubsection{Highstand systems tract (HST)}

The progradational siliciclastic successions of the south-western Dra Plain are interpreted to be highstand systems tracts, whose higher-order cycles are predicted to pinch out basinwards. In the Dra Plain transect, this was not observed, due to the shoreline-parallel orientation. Some of the higher-order cycles resemble the depositional sequences in that thin limestones beds transgress over the coarsening-upward units.

Little carbonate material would be delivered into the basin during highstands, leading to reduced sedimentation to non-deposition below the limestone units. 


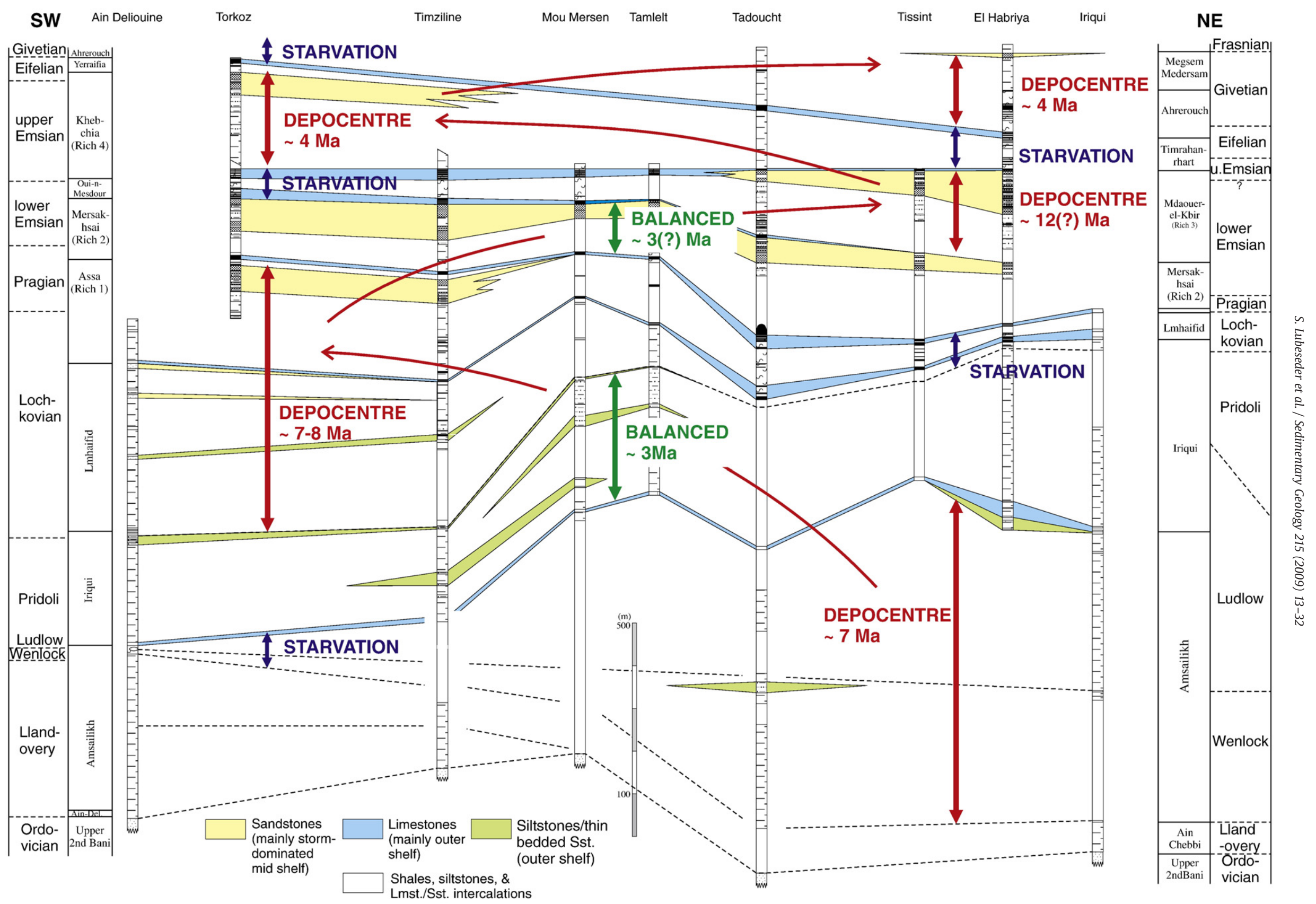

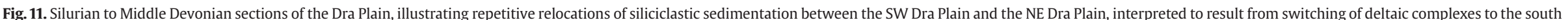
of the study area in the Tindouf Basin. Siliciclastic sedimentation is opposed by starved limestone deposition. Silurian formation ages after Hollard (1977) and Destombes et al. (1985). 


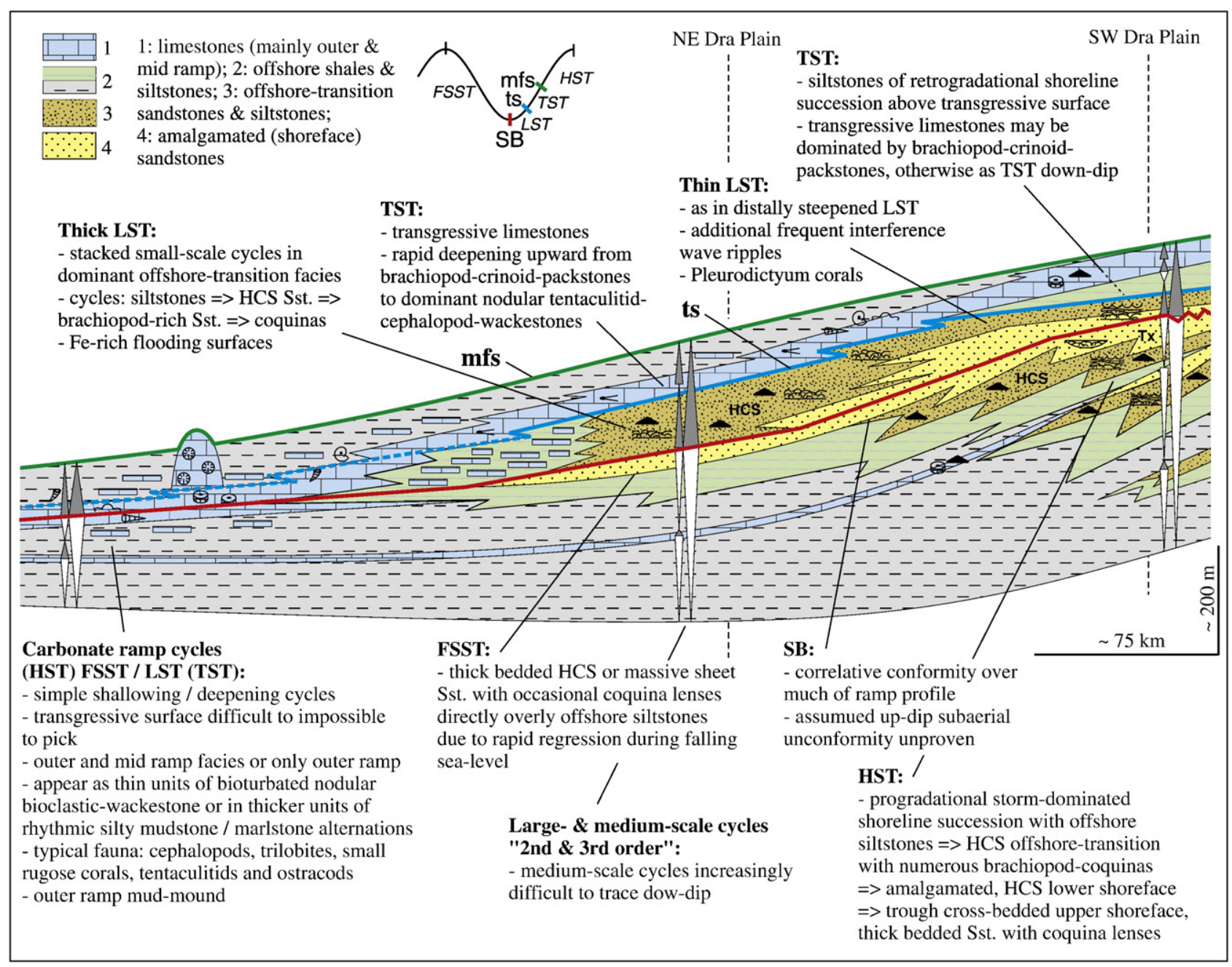

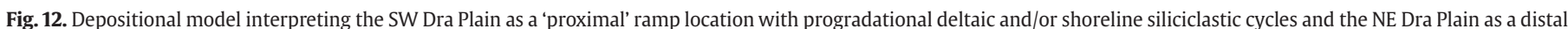

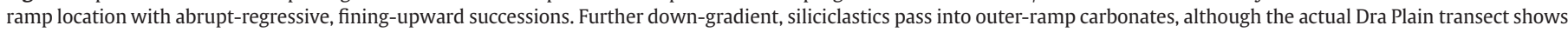

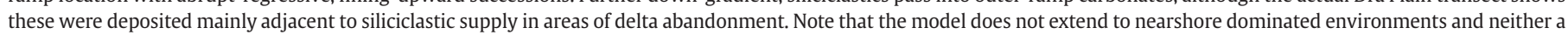
subaerial unconformity nor sandstones of the TST have been recorded.

\subsubsection{Falling stage systems tract (FSST)}

According to the ramp model of Plint and Nummedal (2000), a regressive surface of marine erosion (RSME) underlies FSST deposits. Such a surface may be developed at the base of some of the shoreface sandstones of the south-western Dra Plain proximal ramp (e.g. ripcurrent channels of the Assa Fm), but in most cases the interpretation of this surface appears enigmatic, within an increasingly scoured and amalgamated succession of shelf to shoreface storm beds.

The thick bedded sandstone packages of the north-eastern Dra Plain, resting more or less directly on offshore shales and siltstones, are interpreted to have been deposited during falling relative sea-level (FSST). How much of underlying shales and siltstones belong to the HST or FSST is speculative in the shoreline parallel transect, because higher-order cycles cannot be correlated from the basin margin downdip, and consequently the marked onset of forced regression cannot be delineated. The FSST deposits in this distal ramp location are interpreted to result from the unique environmental conditions at this time of the relative sea-level curve. Due to the combination of maximum sedimentation and preservation rates as well as stormfrequency within the basinal section, distally amalgamated HCS sandstones and massive sheet sandstones are deposited. Interestingly, brachiopod-coquinas are not encountered in this facies, but are abundant in the preceding highstand deposits in the proximal ramp, as well as the following lowstand deposits. Lower sedimentation rates and some time of repeated reworking favours brachiopod-coquina formation (Kidwell, 1991; Brett, 1995; Tomasovych et al., 2006); a circumstance that is in part aided by the hinge mechanism in the brachiopods that prevents rapid post-mortem disarticulation (Copper, 1997). The lack of these deposits in the distal FSST thus confirms relatively high sedimentation and burial rates.

The limestone units in the basin are interpreted to have formed largely during relative sea-level lowstands (FSST and LST), due to the increased supply of carbonate material through storm suspension. Parts of the FSST are likely to be diluted by terrigenous supply in the vicinity of deltaic sediment input (e.g. silty mudstone/marl alternations of the Sellanarcestes Limestone in the SW).

\subsubsection{Sequence boundary}

Continued progradation in the proximal ramp would theoretically lead to the formation of a subaerial unconformity. However, no indications for exposure, incision or ravinement cutting through shoreface sandstones (ravinement-unconformable, cf. Embry, 2002) have been found in any of the studied sections. Only in one location (Assa Formation, Torkoz section) upper shoreface sandstones were presumably deposited close to a subaerial unconformity, since this formation thins dramatically towards a petroleum well located some 30-40 km further to the south. 
The correlative sequence boundary is placed above these shoreface sandstones in the proximal ramp and above amalgamated offshoretransition zone sandstones in the distal ramp.

\subsubsection{Lowstand systems tract (LST)}

The thick FU-intervals of the north-eastern Dra Plain are interpreted as lowstand systems tract (LST) deposits. The LSTs are defined at the base by the maximum regression and shallowest facies observed within the sequence. They comprise aggradationally to retrogradationally stacked successions of small-scale storm bed cycles with abundant brachiopods-coquinas and Fe-enriched flooding surfaces in the middle. A sharp transgressive surface below the overlying limestone units defines the top of the LSTs. Although these lowstand systems tracts share the aggradational pattern typical of LSTs, they deviate from the common models in that they display an overall deepening-upward ('transgressive'), not shallowing-upward ('regressive') trend. This is interpreted to be due to the distal ramp location of the described systems tracts, where a decrease in storm intensity and frequency is already evident during the initial sea-level rise. The deepening-upward of these LSTs could also be related to some distally steepening of the shelf and increased subsidence. In such case, eustatic sea-level rise combined with subsidence on the shelf margin would result in a relative sea-level rise and transgression, as opposed to the normal regression under average subsidence rates (Catuneanu, 2006).

A thin unit interpreted to be the equivalent of the lowstand systems tract is also developed in some of the 'proximal' ramp successions of the south-western Dra Plain.

The alternative to the LST-interpretation is to place all deposits above the maximum regressive surface and FSST into a transgressive systems tract (TST). However, the start of limestone deposition (or siltstones in the proximal ramp) above the interpreted LST deposits is such an abrupt deepening-event, that this is thought to coincide with the highest rate of relative sealevel rise and the transgressive surface that marks the boundary to the carbonate-dominated TST. A TST-interpretation for these siliciclastics would also contradict the general theory that TSTdeposits retrograde quickly on ramps.

In the siliciclastic-starved areas, the outer ramp carbonates of the FSST and LST have relatively sharp bases and beds thin upwards ('Lochkovian Limestones' and basal Mersakhsai Formation limestones of the north-east); an asymmetry that is identical to the FSST/LSTs of the distal ramp siliciclastic successions.

\subsubsection{Transgressive surface}

A sharp transgressive surface overlies the LST with a distinct change in litho- and biofacies. Three main types of transgressive surfaces are distinguished, each being related to different locations on the ramp profile.

a) Outer-ramp nodular wackestones and mudstones with a hemipelagic fauna directly rest on typical offshore-transition zone sandstones (e.g. Mersakhsai and Mdaouer-el-Kbir Fm. of the Tadoucht section, Fig. 5b,c). This type occurs in the most downdip successions.

b) A thin unit, usually 1 metre or less in thickness, consisting of midramp cross-bedded, quartziferous brachiopod-crinoid-limestones and coquinas rests on typical offshore-transition sandstones and precedes the outer-ramp limestones. This is the most common type (e.g. base Timrhanrhart Formation of the Tissint and El Habriya sections; base Oui-n-Mesdour Formation of the Tamlelt, Mou Mersen, Timziline, and Torkoz sections) and appears in intermediate locations on the ramp-profile.

c) Limestones with either a mid ramp facies or transitional mid to outer ramp facies are separated from the Rich-sandstones by a several metre thick siltstone dominated unit. This type is restricted to the south-western Dra Plain (base Mersakhsai Formation of the Timziline and Torkoz sections; top Khebchia Formation of the Torkoz section) and documents the up-dip type of a transgressive surface. The above siltstone dominated unit represents a higherorder sedimentary cycle of the retrograding shoreline, which precedes the deposition of mid-ramp bioclastic limestones during the rest of the TST.

\subsubsection{Transgressive systems tract (TST)}

The limestone units were deposited within the transgressive systems tract. These are organised into two or three higher-order, deepening-upward hemi-cycles. Shallowing-upward trends are thin, which gives these cycles a strong asymmetry. Many transgressive limestones are characterised by a conspicuous faunal change up section towards deeper-water assemblages. This change is sometimes accompanied by a colour change from lighter to dark colours.

As a result of the strong landward shift of facies belts during transgression, the only siliciclastic transgressive deposits in the study area are the siltstone units underlying the limestones in the southwestern Dra Plain. Transgressive sandstones are likely to occur further to the south in the Tindouf Basin.

During transgression, as was the case during the highstand, little carbonate material was delivered into the basin. A transgressive surface is tentatively placed on top of the main limestone units in the basinal sections, which record an abrupt decrease, not the end, of carbonate supply.

\subsubsection{Maximum flooding surface}

The maximum flooding surface is situated directly on top of the transgressive limestones or close to the base of the overlying shales. The top of the Sellanarcestes Limestone in the north-eastern Dra Plain contains abundant ammonoids in some sections, suggesting strong condensation (Fig. 5d). The bulk of the overlying shales are interpreted as pro-delta deposits of the following highstand systems tract.

\subsection{Lowstand systems tract position within the $T / R$-sequence model}

While depositional sequence models and their terminology is frequently applied in sedimentological analysis of a basin, it is the recognition of transgressive-regressive cycles (or sequences) which are more commonly used for inter-regional and global correlation (e.g. Johnson et al., 1985; Gradstein et al., 2004). The comparison of these two concepts is an essential but not easy task and may differ among different basinal settings or even from sequence to sequence.

In transgressive-regressive sequences (T/R-sequences), the HST, FSST, and LST are usually placed into the regressive limb, while the transgressive limb represents the TST only (Embry, 2002; Catuneanu et al., 2005, Catuneanu, 2006). That this is not always the case can easily be foreseen for those distal settings, in which not the sedimentsupply is the major control on sequence architecture but the wavebase; e.g. Palaeozoic hemi-pelagic carbonate ridges without high biological productivity.

This study shows that distal shelf sandstone sequences may show a 'transgressive' (deepening-upward) and not a 'regressive' (shallowing-upward) character within a LST. The sequence boundary and maximum regression may be clearly separated from a later marked transgressive surface. In this case the transgressive limb of such T/R-cycles combines the LST and the TST, not the TST alone (Fig. 13).

\subsection{Early Devonian sequences}

Since the stratigraphic framework of the Rich-cycles were initially established (Hollard, 1967; Bultynck and Hollard, 1980; Hollard, 1981a, b), more recent biostratigraphic work (Lazreq and Ouanami, 1998; Jansen, 2001; El Hassani, 2004; Jansen et al., 2007) together with the 
Catuneanu et al, 2005

Rich-cycles of this study

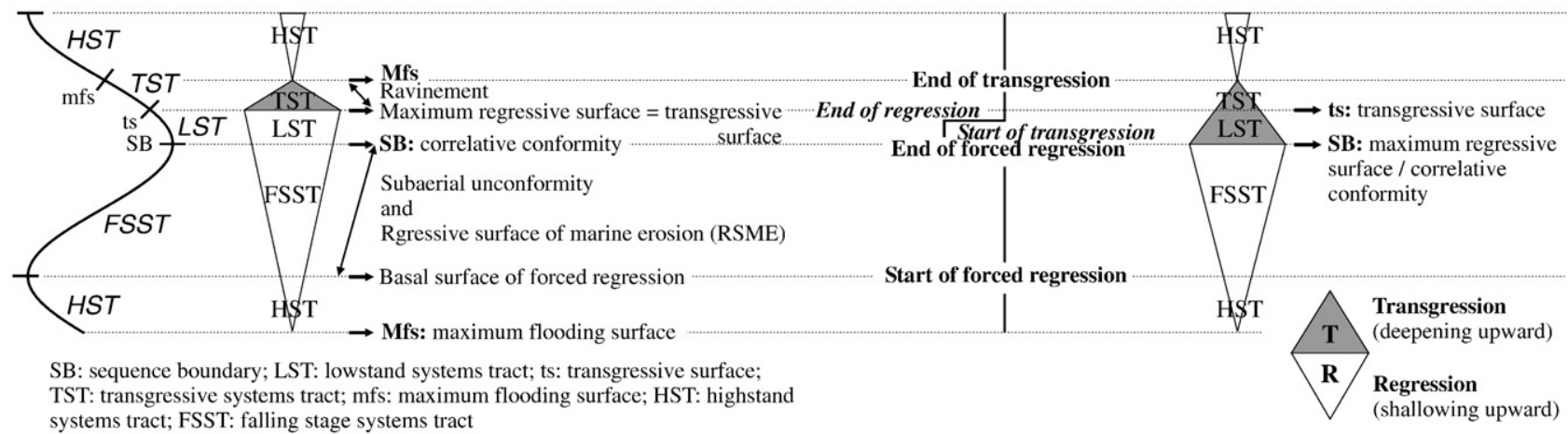

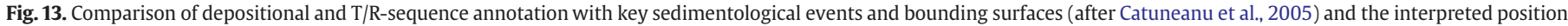
of the LST within the Rich-cycle T/R-sequences of the Anti-Atlas (this study).

additional data from this study (Lubeseder, 2005) have increased the control on sequence ages, although further precision is desirable and essential for some formations.

Four sequences are defined by the Rich-cycles, termed here ED1, ED2, ED3, ED-MD for regional correlation (Fig. 14), which range in duration from 3.5 to $8.5 \mathrm{Ma}$. Sequences ED1, ED-MD, and MD1 can be further subdivided into higher-order T/R-cycles, whose regional correlation potential is however in most cases uncertain.
The sequences generally compare well with the proposed eustatic T/R-cycles from Euramerica (Johnson et al., 1985, 1996; Fig. 14). Differences are a Dra Plain maximum transgression during the mid Lochkovian, rather than late Lochkovian. The succeeding maximum regression in the Dra Plain appears to date to the mid Pragian (late Lower Siegenian, Jansen, 2001) and does not correlate with the Lochkovian-Pragian boundary.

The maximum transgression of sequence ED2 around the PragianEmsian boundary is also recognised on the eustatic curve. The

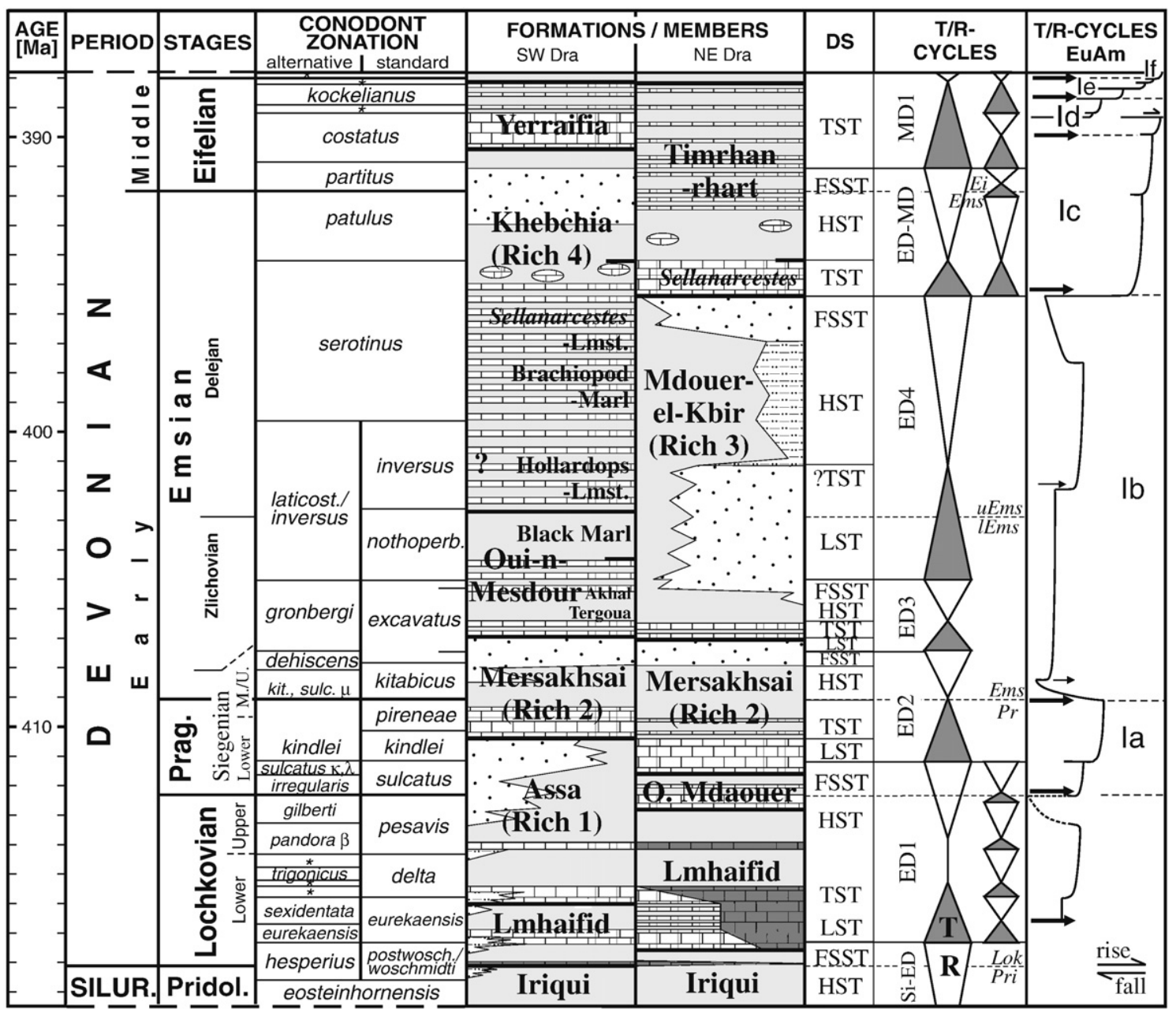

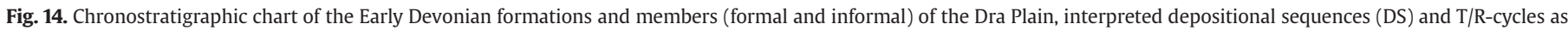
well as the EurAmerican T/R-cycles and sea-level curve of Johnson et al. $(1985,1996)$ for comparison. Devonian time-scale after Kaufmann $(2006)$. 
following maximum regression is thought to be slightly younger in the Dra Plain (probably transition kitabicus-excavatus Zone) than on the eustatic curve.

The transgressive surface above this sequence boundary may well correlate with the base-Zlichov event (Jansen et al., 2004; base ED3). The eustatic curve does not show the early Emsian regression of sequence ED3, which is suggested in the Dra Plain by the lower part of the Mdaouer-el-Kbir sandstones. The correlation of this regressive phase into the south-western Dra Plain is uncertain, where it is interpreted to coincide with the upper part of the Akhal Tergoua Member of the Oui-n-Mesdour Formation.

The maximum transgressive surface of sequence ED4 on top of the lower Mdaouer-el-Kbir Formation sandstones (phosphatic horizons in the El Habriya section; Fig. 9) is tentatively correlated to the mid Emsian eustatic transgressive event (Daleje Event). As in the preceding sequence, the correlation of this flooding event into the south-western Dra Plain is uncertain. The current age proposals (Becker et. al., 2004) imply the event should be situated within the Brachiopod Marl Member between the Hollardops and the Sellanarcestes Limestone members of the lower Khebchia Formation. However, field work during this study did not find any indications, which suggest a transgressive event at this level. Both limestone members and the Brachiopod Marl Member seem to be one genetic unit, which cannot be differentiated by lithofacies. An alternative level of the Daleje Event could be the lower part of the Hollardops Member showing dark shale intercalations (pers. comm. U. Jansen).

The regression of the upper Mdaouer-el-Kbir Formation sandstones and the directly following marked transgression of the Sellanarcestes Limestones both correspond to the late Emsian regressive-transgressive pulses on the eustatic curve.

The latest Emsian regression as suggested by the upper Khebchia Formation sandstones does not show on the eustatic curve. The following transgressive surfaces at the base of the Yerraifia Formation could correlate with the global Chotec transgressive event (mid partitus to lower part costatus Zone; e.g. House, 2002).

\section{Conclusions}

The Lower Devonian succession of the Dra Plain displays very well defined sequences composed of storm-dominated shelf siliciclastics and shelf limestones. Two stacking patterns are developed in the siliciclastic units: normal progradational shoreline successions in a proximal ramp location (mainly HST) and an abrupt-regressive successions in a more distal ramp location (mainly FSST), where thick lowstand systems tracts are recognised. Time-transgressive limestones of the transgressive systems tract overlie a well defined transgressive surface.

The lowstand systems tract is bound by a marked maximum regressive surface at the base and a marked transgressive surface at the top. In contrast to the T/R-sequence model, the two surfaces are not identical. The stacking pattern in between the two surfaces is aggradational to retrogradational and the lowstand systems tract shows a deepening-upward facies trend and thus is 'transgressive' (to stillstand) in character. In this respect the systems tract characteristics differ from previous depositional sequence models for siliciclastic ramps (aggradational to progradational, regressive LST; Plint and Nummedal, 2000). The difference is probably related to a slight distally steepening and increased subsidence in the north-eastern Dra Plain, in which case the initial relative sea-level rise outpaces continued sediment supply into the basin.

The mixed siliciclastic-carbonate system of the Dra Plain offers the opportunity to feed observations from one component (carbonate dominated) into the facies interpretation of the other (siliciclastic dominated). In siliciclastic shelf sandstone sequence analysis, thicker sandstone packages may be misinterpreted as near-shore deposits. The close lateral association of some of these sandstones in the Dra
Plain with typical outer ramp carbonates, strongly suggests significant amalgamation of mid to outer shelf, fine-grained sandstones and siltstones during 'lowstand' conditions (FSST/LST) into prominent sheet-like sandstone bodies.

In the study area the distribution of shelf sandstones and siliciclastic depocentres was controlled by long-term switching of deltaic complexes, presumably as a result of basin-fill and subsidence interplay to the south of the Anti-Atlas. In abandoned shelf areas, starved carbonate sequences developed with typical outer ramp lithofacies types. The recognition of such spatial/temporal sediment distribution in-between sub-basins, separated by palaeohighs, is important for regional correlation and petroleum exploration. Similar controls may have governed the sediment distribution in other parts of the Saharan Platform, from which many elongated, shorelineperpendicular palaeohighs of different size and topography are known to have existed throughout the Palaeozoic.

The depositional system and sequence analysis suggests a strong diachronism of lithological units. The transgressive surface, a near time-line, for example, overlies the basinal limestone units outside the siliciclastic supply in starved sections, but underlies the same lithological marker, where it occurs above the siliciclastic shelf wedges. Comparable, the progradational sandstone successions (HST) of the proximal ramp (SW Dra Plain) are older than similar lithological units in the distal ramp (NE Dra Plain), which belong to the aggradational to retrogradational stacked LST. Recognition of such diachronism may become extremely important if fossil assemblages are compared from the same lithological unit (formation) in different areas.

\section{Acknowledgements}

The study was funded by the North Africa Research Group (Manchester) sponsored by Hess, Anadarko, BG, Burlington, ConocoPhilips, Edison, Maersk, Occidental, RepsolYPF, Wintershall and Woodside.

Thanks are to Zdzislaw Belka (Poznan) for the analysis of the conodont samples and to Christian Klug (Zürich) for the determination of the ammonoids.

We would like to thank ONHYM (Rabat) for helping greatly with logistics and shipping the samples.

\section{References}

Becker, R.T., Kirchgasser, W.T., 2007. Devonian events and correlation. Geol. Soc. Spec. Publ. 278, 280.

Becker, R.T., Jansen, U., Plodowski, G., Schindler, E., Aboussalam, S.Z., Weddige, K., 2004. Devonian litho- and biostratigraphy of the Dra Valley area-an overview. In: El Hassani, A. (Ed.), Devonian of the western Anti Atlas: correlations and events. Doc. Inst. Sci., Rabat, vol. 19, pp. 3-18.

Berry, W.B.N., Boucot, A.J., 1973. Correlation of the African Silurian rocks. Spec. Pap. Geol. Soc. Am. 147, 83.

Boote, D.R., Clark-Lowes, D.D., Traut, M.W., 1998. Palaeozoic petroleum systems of North Africa. In: MacGregor, D.S., Moody, R.T.J., Clark-Lowes, D.D. (Eds.), Petroleum Geology of North Africa. Geol. Soc. London Spec. Publ., vol. 132, pp. 7-68.

Boumendjel, K., Morzadec, P., Paris, F., Plusquellec, Y., 1997. Le Devonien de L'Ougarta (Sahara Occidental, Algeri). Ann. Soc. Géol. Nord 5, 123-128.

Brett, C.E., 1995. Sequence stratigraphy, biostratigraphy, and taphonomy in shallow marine environments. Palaios 10, 597-616.

Bultynck, P., Hollard, H., 1980. Distribution comparée de conodonts et goniatites dévoniens des plaines du Dra, du Ma'der et du Tafilalt (Maroc). Aardkd. Meded. 1, 9-73.

Bultynck, P., Walliser, O.H., 2000. Devonian boundaries in the Moroccan Anti-Atlas. Cour. Forsch.-Inst. Senckenb. 225, 211-226.

Burchette, T.P., Wright, V.P., 1992. Carbonate ramp depositional systems. Sediment. Geol. 79, 3-57.

Caritg, S., Burkhard, M., Ducommun, R., Helg, U., Kopp, L., Sue, C., 2004. Fold interference patterns in the Late Palaeozoic Anti-Atlas belt of Morocco. Terra Nova 16, $27-37$.

Catuneanu, O., 2006. Principles of Sequence Stratigraphy. Elsevier, Amsterdam.

Catuneanu, O., Martins-Neto, M.A., Erikson, P.G., 2005. Precambrian sequence stratigraphy. Sediment. Geol. 176, 67-95.

Coniglio, M., James, N.P., 1990. Origin of fine-grained carbonate and siliciclastic sediments in an Early Palaeozoic slope sequence, Cow Head Group, western Newfoundland. Sedimentology 37, 215-230. 
Copper, P., 1997. Articulate brachiopod shellbeds: Silurian examples from Anticosti, Eastern Canada. Geobios 20, 133-148.

Copper, P., 2002. Silurian and Devonian reefs: 80 million years of global greenhouse between two ice ages. Spec. Publ. - Soc. Econ. Paleontol. Mineral. 72, 181-238.

Destombes, J., Hollard, H., Willefert, S., 1985. Lower Palaeozoic rocks of Morocco. In: Holland, C.H. (Ed.), Lower Palaeozoic of Northwestern and west central Africa. John Wiley \& Sons, pp. 91-336.

El Hassani, A., 2004. Devonian of the western Anti Atlas: correlations and events. Doc. Inst. Sci., Rabat 19, 100

Embry, A.F., 2002. Transgressive-Regressive (T-R) sequence stratigraphy. 22nd Annual Gulf Coast Section SEPM Foundation Bob F. Perkins Research Conference, pp. 151-172.

Frakes, L.A., Francis, J.E., Syktus, J.I., 1992. Climatic Modes of the Phanerozoic. Cambridge University Press, Cambridge.

Gradstein, F.M., Ogg, J.O., Smith, A.G., 2004. A Geological Time Scale 2004. Cambridge University Press, Cambridge.

Hampson, G.J., Storms, J.E.A., 2003. Geomorphological and sequence stratigraphic variability in wave-dominated, shoreface-shelf parasequences. Sedimentology 50, 667-701.

Hollard, H., 1967. Le Devonien du Maroc et du Sahara Nord-Occidental. In: Oswald, D.H. (Ed.), International Symposium on Devonian System. Alberta Soc. Petrol. Geol., Calgary, vol. II, pp. 203-244.

Hollard, H., 1977. Le domaine de l'Anti-Atlas au Maroc. In: Martinsson, A. (Ed.), The Silurian-Devonian Boundary. IUGS Series A 5. Schweizerbart, Stuttgart, pp. 168-194.

Hollard, H., 1978. Corrélations entre niveaux à brachiopodes et à goniatites au voisinage de la limite Dévonien inférieur-Dévonien moyen dans les plaines du Dra (Maroc présaharien). Newsl. Stratigr. 7, 8-25.

Hollard, H., 1981a. Principaux caractères des formations dévoniennes de l'Anti-Atlas. Notes Mem. Serv. Géol. Maroc 308, 15-22.

Hollard, H., 1981b. Tableaux des corrélations du Silurien et du Dévonien de l'Anti Atlas. Notes Mem. Serv. Géol. Maroc 308, 23-46.

Homewood, P.W., Eberli, G.P., 2000. Genetic Stratigraphy on the Exploration and Production Scales: Case Studies from the Pennsylvanian of the Paradox Basin and the Upper Devonian of Alberta. Bull. Centr. Rech. Elf Explor. Prod., Memoir, vol. 24. Pau.

House, M.R., 2002. Strength, timing, setting and cause of mid-Palaeozoic extinctions. Palaeogeogr., Palaeoclimatol., Palaeoecol. 181, 5-25.

James, N.P., 1997. The cool-water carbonate depositional realm. In: James, N.P., Clarke, J.A.D. (Eds.), Cool-Water Carbonates. Spec. Publ. - Soc. Econ. Paleontol. Mineral., vol. 56, pp. 1-20.

Jansen, U., 2001. Morphologie, Taxonomie und Phylogenie unter-devonischer Brachiopoden aus der Dra-Ebene (Marokko, Prä-Sahara) und dem Rheinischen Schiefergebirge (Deutschland). Abh. Senckenb. Naturforsch. Ges. 554, 389.

Jansen, U., Becker, T., Plodowski, G., Schindler, E., Vogel, O., Weddige, K., 2004. Pragian and Emsian near Aouinet Torkoz (SW Dra Valley, Morocco). In: El Hassani, A. (Ed.), Devonian of the western Anti Atlas: correlations and events. Doc. Inst. Sci, Rabat, vol. 19, pp. 75-84.

Jansen, U., Lazreq, N., Plodowski, G., Schemm-Gregory, M., Schindler, E., Weddige, K., 2007. Neritic-pelagic correlation in the Lower and basal Middle Devonian of the Dra Valley (Southern Anti-Atlas, Moroccan Pre-Sahara). In: Becker, R.T., Kirchgasser, W.T. (Eds.), Devonian Events and Correlation. Geol. Soc. Spec. Publ., vol. 278, pp. 9-37.
Johnson, J.G., Klapper, G., Sandberg, C.A., 1985. Devonian eustatic fluctuations in Euramerica. Geol. Soc. Am. Bull. 96, 567-587.

Johnson, J.G., Klapper, G., Elrick, M., 1996. Devonian Transgressive-Regressive cycles and biostratigraphy, Northern Antelope Range, Nevada: establishment of reference horizons for global cycles. Palaios 11, 3-14.

Kaufmann, B., 2006. Calibrating the Devonian time scale: a synthesis of U-Pb ID-TIMS ages and conodont stratigraphy. Earth-Sci. Rev. 76, 175-190.

Kidwell, S.M., 1991. The stratigraphy of shell concentrations. In: Allison, P.A., Briggs, D.E.G. (Eds.), Taphonomy: Releasing the Data Locked in the Fossil Record. Plenum Press, New York, pp. 211-290.

Kriz, J., 2000. Lochkovian bivalves of Boehemian type from the eastern Anti-Atlas (Lower Devonian, Morocco). Senckenb. Lethaea 80, 485-523.

Lazreq, N., Ouanami, H., 1998. Le Devonien inferieur de Tizi-n-Tichka (Haut Atlas) et de Laayoune (Tata, Anti-Atlas, Maroc): Nouvelles datations et implications paleogeographiques. Senckenb. Lethaea 77, 223-231.

Lubeseder, S., 2005. Silurian and Devonian Sequence Stratigraphy of North Africa: regional correlation and sedimentology (Morocco, Algeria, Libya). Ph.D. thesis University of Manchester, UK.

Lubeseder, S., 2008. Palaeozoic low-oxygen, high-latitude carbonates: Silurian and Lower Devonian nautiloid and scyphocrinoid limestones of the Anti-Atlas (Morocco). Palaeogeogr. Palaeoclimatol. Palaeoecol. 264, 195-209.

Lüning, S., Craig, J., Loydell, D.K., Štorch, P., Fitches, B., 2000. Lower Silurian 'hot shales' in North Africa and Arabia: regional distribution and depositional model. Earth-Sci. Rev. 49, 121-200.

Plint, A.G., Nummedal, D., 2000. The falling stage systems tract: recognition and importance in sequence stratigraphic analysis. In: Hunt, D., Gawthorpe, R.L. (Eds.) Sedimentary Responses to Forced Regressions. Geol. Soc. London Spec. Publ., vol. 172, pp. $1-17$.

Reading, H.G., 1996. Sedimentary Environments: Processes, Facies and Stratigraphy. Blackwell Science, Oxford.

Schraut, G., 2000. Trilobiten aus dem Unter-Devon des südöstlichen Anti-Atlas, SüdMarokko. Senckenb. Lethaea 79, 361-433.

Scotese, C.R., McKerrow, W.S., 1990. Revised world maps and introduction. In: McKerrow, W.S., Scotese, C.R. (Eds.), Palaeozoic Palaeogeography and Biogeography. Geol. Soc. London Mem., vol. 12, pp. 1-21.

Stampfli, G.M., Borel, G.D. 2002. A plate tectonic model for the Paleozoic and Mesozoic constrained by dynamic plate boundaries and restored synthetic oceanic isochrones. Earth Planet. Sci. Lett. 196, 17-33.

Taylor, P.D., Wilson, M.A., 2003. Palaeoecology and evolution of marine hard substrate communities. Earth-Sci. Rev. 62, 1-103.

Tomasovych, A., Fürsich, F.T., Wilmsen, M., 2006. Preservation of autochthonous shel beds by positive feedback between increased hardpart-input rates and increased sedimentation rates. J. Geol. 114, 287-312.

Walker, R.G., Plint, A.G., 1992. Wave and storm-dominated shallow marine systems. In: Walker, R.G., James, N.P. (Eds.), Facies Models: Response to Sea-Level Change. Geological Association of Canada, St John's, Newfoundland, pp. 219-238. 